\title{
Peshtasar basalts: An example of post-collision basalts in sedimentary basin of Moghan, NW Iran
}

\author{
Abbasali Amraee ${ }^{1}$, Reza Zareisahamieh ${ }^{1, *}$, Mohsen Moayyed $^{2}$, \\ Ahmad Ahmadikhalaji ${ }^{1}$, Amirmorteza Azimzadeh ${ }^{3}$ and Jose Francisco Santos ${ }^{4}$ \\ ${ }^{1}$ Department of Geology, Faculty of Sciences, Lorestan University, Khorramabad, Iran. \\ ${ }^{2}$ Department of Earth Sciences, Faculty of Natural Sciences, University of Tabriz, Tabriz, Iran. \\ ${ }^{3}$ Department of Geology, Faculty of Sciences, Zanjan University, Zanjan, Iran. \\ ${ }^{4}$ Geobiotec, Departamento de Geociencias, Universidade de Aveiro, 3810-193 Aveiro, Portugal. \\ *Corresponding author.e-mail: zarei.r@lu.ac.ir
}

MS received 5 February 2018; revised 15 June 2018; accepted 19 June 2018; published online 11 March 2019

With an east-west exposure trend, Peshtasar Complex, which is located in the sedimentary basin of Moghan, northwestern Iran, is lithologically varied. The main constituent minerals are plagioclase, clinopyroxene and iddingsitised olivine in basalts and plagioclase megacryst, clinopyroxene and leucite in tephrite. The studied rocks are plotted in the fields of basaltic trachy-andesite, trachy-andesite and tephri-phonolite in the total alkali-silica (TAS) diagram as well as high-K to calc-alkaline and shoshonite fields. The chondrite normalised pattern of rare earth elements indicates the enrichment of LILE and LREE as well as the depletion of HFSE and HREE. Nb and Ti have a negative anomaly in the spider diagram. $\mathrm{Eu} / \mathrm{Eu}^{*}$ represents a positive anomaly for Eu indicating the frequency of calcic plagioclase and low oxygen fugacity in rocks. Geochemical parameters and diagrams predict a magmatic evolution via assimilation - fractional crystallisation process. According to the $\mathrm{Ce} / \mathrm{Yb}$ vs. Ce diagram, partial melting has happened within the garnet-lherzolite field in the depth of $\sim 100 \mathrm{~km}$. Based on ${ }^{87} \mathrm{Sr} /{ }^{86} \mathrm{Sr}$, Shahyourdi samples have EM1 sources, whereas Germi and Tazehkand basalts have EM11 sources that are indicative of different mantle sources for basalts in the western Moghan of the central and eastern areas. Basalts are found in active continental margins associated with the post-collision arcs.

Keywords. Moghan basin; Peshtasar basalt; post-collision arc; geochemistry; isotopic analysis.

\section{Introduction}

Eocene volcanic activity is one of the most important magmatic phenomena in Iran. Its effects can be traced in most parts of the country, except for Zagros and Kopeh Dagh. Peshtasar basalts of the Moghan sedimentary basin could be regarded as an example of these activities. Basalts are recognised as basic volcanic rocks that are poor in silica (silica oxide < $53 \mathrm{wt} \%$ ) and rich in $\mathrm{MgO}$ (>5 wt\%) (Le Maitre et al. 1989). The basaltic magma is a primary magma produced by partial melting of a source region of peridotitic rocks (BVSP 1981). Therefore, the study of geochemical characteristics of these rocks, as well as xenoliths entrained in them, provides a lot of information about the composition and mineralogy of their source regions. Basalts erupt in a wide range of tectonic environments. The basaltic magmas are known to be parental to most of the more evolved magmas in oceanic as well as continental environments (Gill 2010). Despite several studies of 
basalts in Moghan sedimentary basin, which have been carried out separately, there is a lack of a comprehensive and systematic study of genesis, tectonics and the source of their parental magmas based on geochemical and isotopic parameters on Peshtasar basalts. Therefore, the present research aims to study their geochemical properties and determine the tectonic setting, magmatic series, the factors affecting the magmatic evolution of Peshtasar basalts and their origin.

\subsection{Geological background}

Moghan sedimentary basin is located in the northwest of Iran and is bounded by longitudes $46^{\circ} 39^{\prime}-$ $48^{\circ} 10^{\prime} \mathrm{E}$ and latitudes $38^{\circ} 30^{\prime}-39^{\circ} 42^{\prime} \mathrm{N}$. There is a vast area in the northern margin of this region which is related to the Kura structural-sedimentary basin. The southern part of Moghan shares its border with Khorosloo heights whereas its northeastern margin is located between the Tazehkand section and Bilehsavar township with a length of $49 \mathrm{~km}$. The opposite margin, however, spreads along a distance of $67 \mathrm{~km}$ from Tazehkand to Aslandoz township. Moghan hydrocarbon basin occupies the southeastern margin of Caucasus sedimentary basin, which lies between the remaining ocean basins of the Caspian Sea and Black Sea (figure 1A). Moreover, the region is limited to the Republic of Azerbaijan in the north and east, Meshkin-Shahr and Ahar in the south and Gharehbagh of Armenia in the west. The roads leading to the studied area are presented in the satellite images (figure 1B).

Talysh basin (Azerbaijan) is mainly covered by the volcanic units of Jurassic-Quaternary, while its southern part spreads towards Iran (Moghan plain). The Peshtasar basalt is named after a village, Peshtasar, in Azerbaijan-Talysh (IFP 1961; Badiozamani 1967). The type section of this basalt, with a thickness of more than $1300 \mathrm{~m}$, is located in Peshtasar village in Azerbaijan-Talysh. The basalt is a dark andesite-basaltic lava and is composed of olivine, augite and plagioclase within a glassy and microcrystalline groundmass. Wellpreserved pillow structures near southern Germi (northeast of Moghan) (figure 2A) and Shahyourdi (west of Moghan) (figure 2B) indicate a submarine eruption. In areas like Tazehkand (figure 2C), Salim Aghaji (figure 2D), Mardlu and Abesh Ahmad basalts are massive without the pillow structure. Salim Aghaji Formation underlies this basalt with a distinct and sharp boundary, while the Lower-Ojagh-Gheshlagh Formation has a sharp contact in its upper boundary. In other words, this basalt, as a specific horizon, separates these two formations and is called Key Horizon B (IFP 1961). The Peshtasar basalt, with an east-west trend, divides upper Eocene sediments of the Talysh basin into two parts (figure 1A). Based on the tectonic divisions by different geologists such as Nabavi (1976), the sedimentary basin of Moghan is considered as a part of western Alborz-Azerbaijan, which is located in the northern part of a wide orogenic zone. However, according to Aghanabati (2004) and Golonka (2004) this basin is located in the Caspian region, Talysh. In fact, Moghan plain is a part of Talysh basin in the Republic of Azerbaijan that elongates towards Iran and has one of the most complete Paratethys deposits. The Qara Su Formation is the first tertiary outcrop of the area. The Gare Aghaj Formation lies on the Qara Su Formation with a discontinuous unconformity and is divided into two parts: the lower part is siliceous, whereas, the upper part is made of shale sand with lava from the late to middle Eocene. From middle to upper Eocene, the formation is gradually replaced with Shekarlu Formation that is composed of marly clay and tuff layers and is overlain by Salim Aghaji Formation.

\subsection{Tectonic structure and geodynamic evolution}

The Moghan area in the northwest of Iran covers about $6500 \mathrm{~km}^{2}$ in northern Ardabil and EastAzerbaijan provinces. In terms of tectonic settings, Moghan basin represents a part of the complex named Talysh-Lesser Caucasus orogenic belt at the southern margin of the Kura basin (figure 3). Moghan basin is located in the northern part of a collision zone in Eurasia-Arab plate. Moghan region is situated in the northern branch of AlpineHimalayan orogenic belt and covers the western folded zone of Talysh area, Pliocene-Quaternary plain on the north and Kura depression on the southern edge. Talysh folded zone is a segment of Lesser Caucasus-Talysh-Alborz system, formed in Late Cenozoic along the northern margin of ArabEurasian collision zone. Kura depression refers to the system of intermountain troughs of Alpine folded belt and separates the structures of the Greater and the Lesser Caucasus. It represents a single basin with South Caspian depression.

Moghan region represents the western part of South Caspian basin. The formation of an intercontinental basin in Moghan region refers to the 

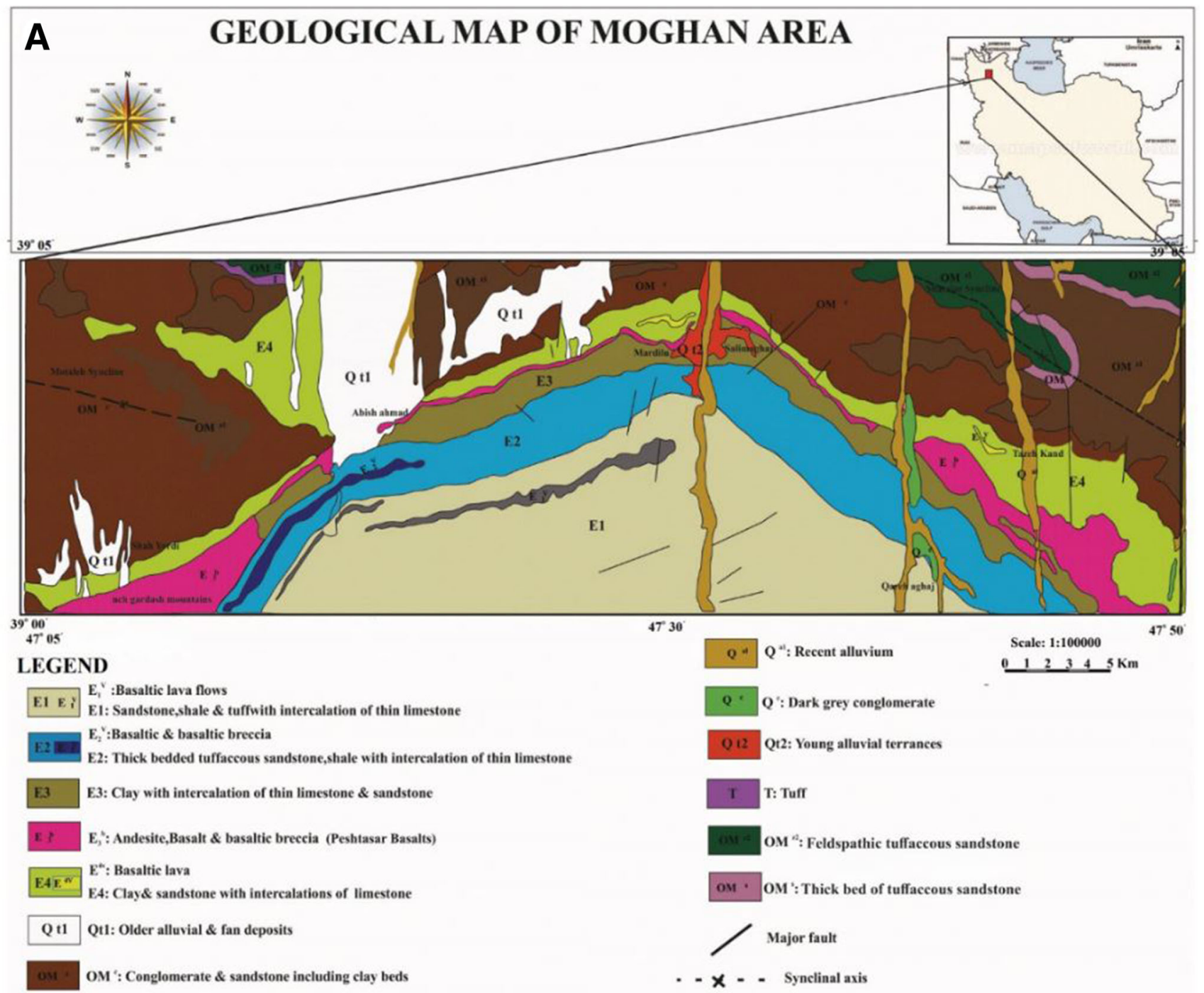

W' ${ }^{\prime \prime}{ }^{\prime \prime}$ : Gypsiferous clay containing limestone nodules

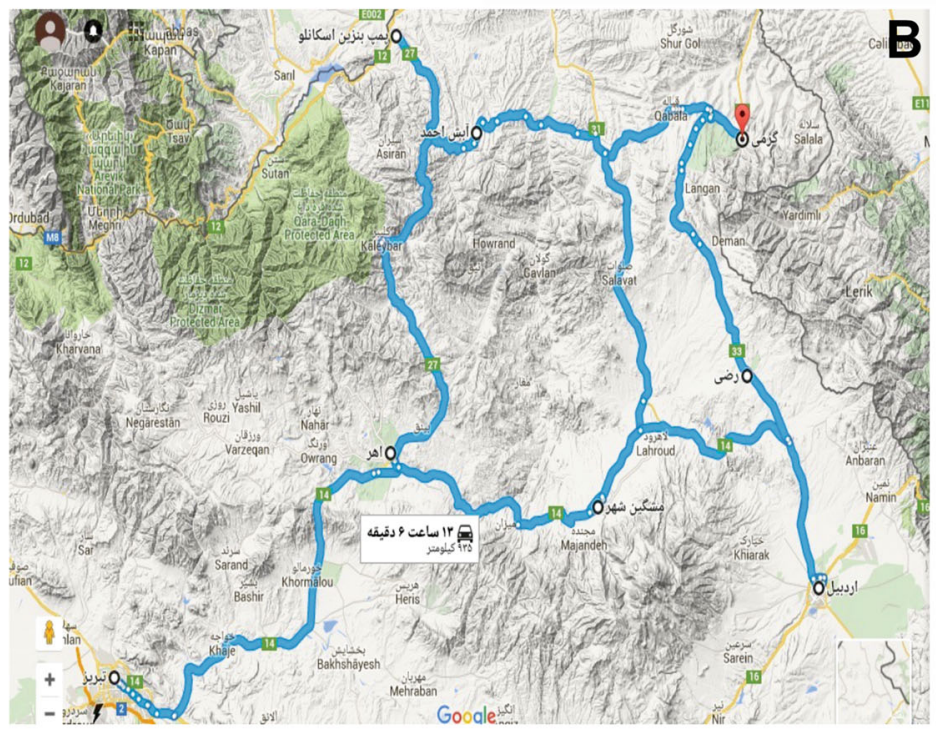

Figure 1. (A) Simplified geological map of the studied area (adapted from maps 1:100,000 Zeiveh and Aslanduz). (B) The leading roads to the studied area in satellite images. 

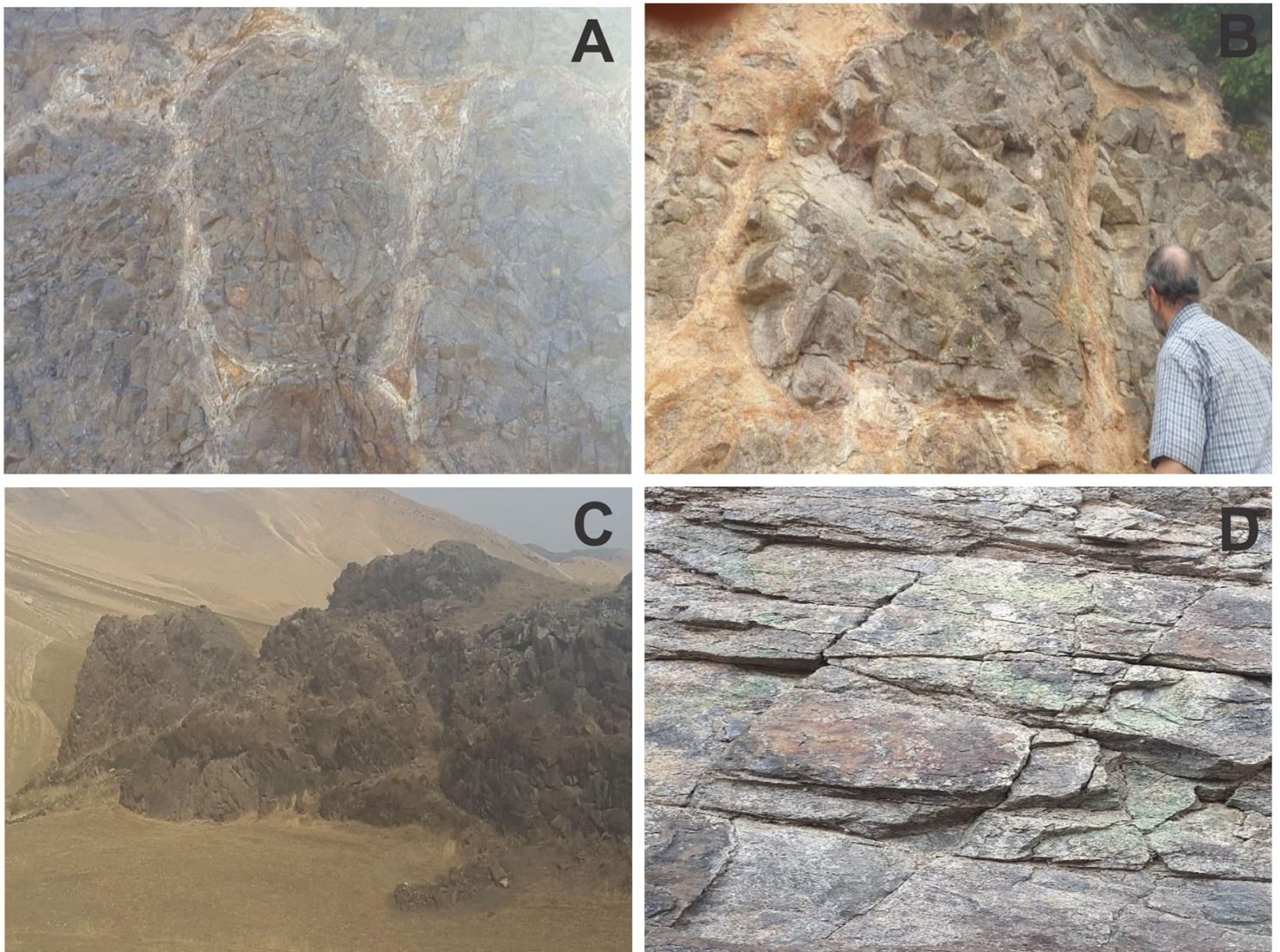

Figure 2. (A) Pillow lava in southern Germi, northeastern Moghan, eastward view. (B) Pillow structure in the west of Moghan, Shahyourdi village, westward view. (C) Massive lava in Moghan centre, Tazehkand village, northward view. (D) Massive lava in Moghan centre, Salim Aghaji village, northward view.

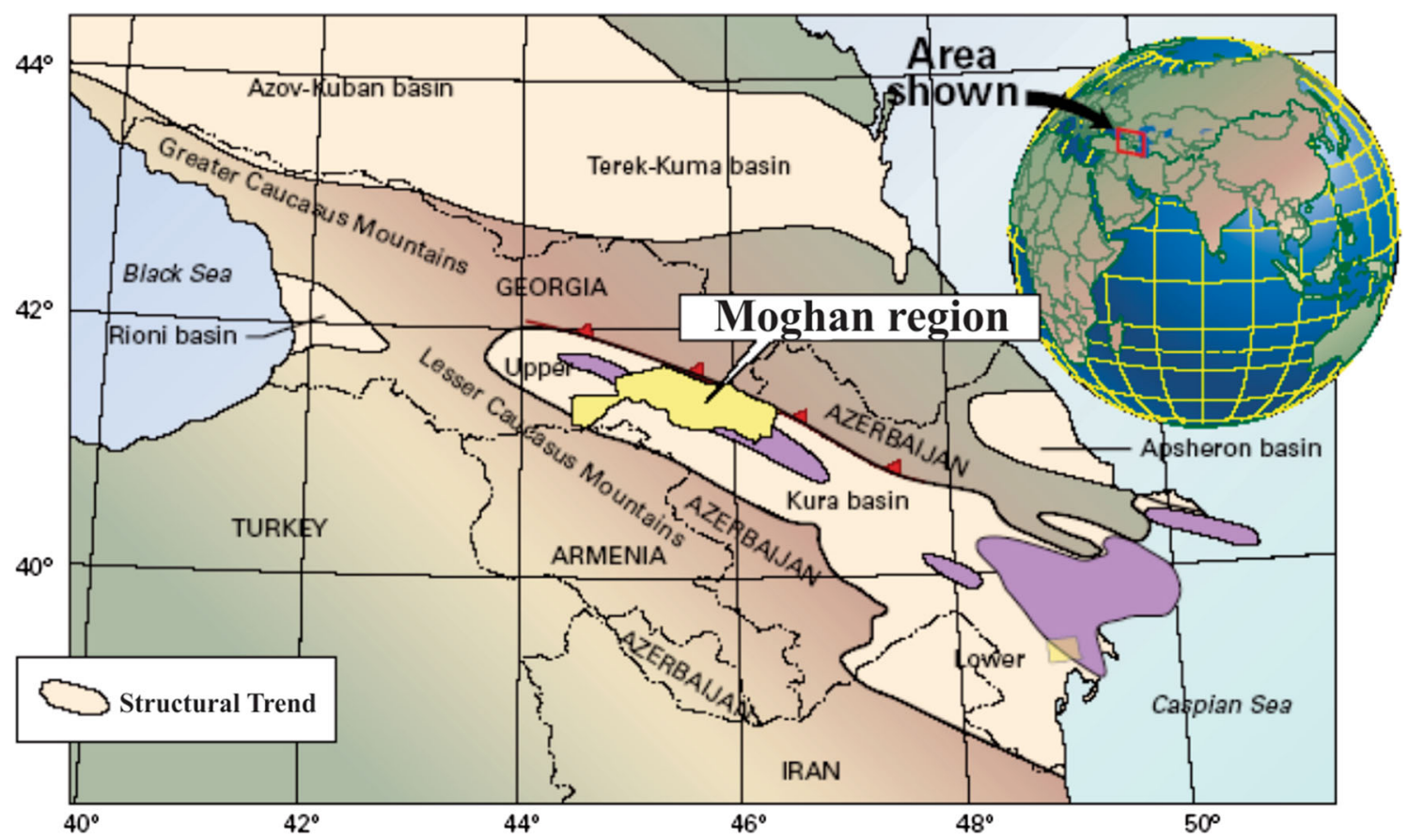

Figure 3. Moghan region position within Kura basin. 
Mesozoic extension phase. An inversion during Cenozoic stages of Arabia-Eurasia collision has exposed the rocks in Alborz, Koppeh Dagh and Binalud mountains in northern Iran, as well as the eastern extent of the Greater Caucasus. The geodynamic evolution and sedimentation of an area stretching from South Caspian basin-eastern Caucasus to Central Iran is mainly controlled by the evolution of two subduction systems closing the Palaeotethys and Neotethys oceans successively (Brunet et al. 2009).

The geology and more importantly the tectonic style of Iran are highly influenced by the development and history of the Tethyan region. The Tethyan region including Iranian plate underwent three major evolutionary stages in relation to the opening and closing of Palaeotethys. The first tectonic events around Iranian plate correlate with rifting of Gondwana. Gondwana break-up was associated with tensional basins and basement highs. The central Iranian block was separated from Arabian plate along High Zagros Zone.

As a consequence Neotethys was opened. The closure of Neotethys started during Late Cretaceous and continued until Cenozoic (data from the dissertation Geological situation of Iran). In the Eocene, a strong extension along normal faults with west-east striking zones was active. The first compressional deformations, which are related to Arabia-Eurasia collision, started in the Late Eocene (Barrier and Vrielynck 2008). Arab-Eurasia convergence took place first in southern Iran. Continent-continent collision generated the main orogenic belts of the Middle East (i.e., the Caucasus-Alborz, southern Turkey and Zagros ranges; Brunet et al. 2009).

\section{Materials and methods}

During various outcrop examinations and field operations, 110 rock samples from the Peshtasar basalt units were collected across the Moghan basin. Following microscopic studies with a polarising microscope, 25 least altered samples of the Peshtasar basalt were analysed for major and trace elements, including rare earth (REE) and high field strength (HFS) elements. Five of these samples were also analysed for $\mathrm{Sr}$ and $\mathrm{Nd}$ isotope compositions. Major and trace elements in the bulk rock were analysed by inductively coupledplasma optical emission spectrometry (ICP-OES) and inductively coupled-plasma mass spectrometry (ICP-MS), respectively, at Zarazma Mineral Studies laboratory. Instrumental precision by ICP-OES for major elements and trace elements was 1$3 \%$ and $3-10 \%$, respectively. Instrumental precision on low-abundance high field strength element (HFSE) and REE is $2-12 \%$, depending on the element and the sample. Trace element content of bulk rocks was obtained by ICP-MS, using multi-element MERCK 6 and AGILENT 1.3 and 4 standards (see results in table 1). Strontium and neodymium isotope compositions were determined at the Laboratory of Isotope Geology of the University of Aveiro, Portugal. The selected powdered samples were dissolved by $\mathrm{HF} / \mathrm{HNO}_{3}$ solution in PTFE-lined Parr acid digestion bombs at a temperature of $180^{\circ} \mathrm{C}$ for 3 days. After evaporation of the final solution, the samples were dissolved in $\mathrm{HCl}(6.2 \mathrm{~N})$ as well as in acid digestion bombs, and dried again. The elements to be analysed were purified using conventional ion chromatography technique in two stages: separation of $\mathrm{Sr}$ and REE in ion exchange columns containing AG8 $50 \mathrm{~W}$ Bio-Rad cation exchange resin followed by the separation of Nd from other lanthanides in columns containing cation exchange Eichrom Ln resin. All reagents used in the preparation of the samples were sub-boiling distilled, and the water was produced by a Milli-Q Element (Millipore) apparatus. Strontium was loaded on a single Ta filament with $\mathrm{H}_{3} \mathrm{PO}_{4}$. Nd, however, was loaded on a Ta outer side filament with $\mathrm{HCl}$ in a triple filament arrangement. ${ }^{87} \mathrm{Sr} /{ }^{86} \mathrm{Sr}$ and ${ }^{143} \mathrm{Nd} /{ }^{144} \mathrm{Nd}$ isotopic ratios were determined using a multi-collector thermal ionisation mass spectrometer VG Sector 54. Data were acquired in dynamic mode with peak measurements at $1-2 \mathrm{~V}$ for ${ }^{88} \mathrm{Sr}$ and $0.5-1.0 \mathrm{~V}$ for ${ }^{144} \mathrm{Nd}$. Typical runs consisted of the acquisition of 60 isotopic ratios. Strontium and neodymium isotopic ratios were corrected for mass fractionation relative to ${ }^{88} \mathrm{Sr} /{ }^{86} \mathrm{Sr}=$ 0.1194 and ${ }^{146} \mathrm{Nd} /{ }^{144} \mathrm{Nd}=0.7219$. During this study, through the SRM-987 standard, the average value of ${ }^{87} \mathrm{Sr} /{ }^{86} \mathrm{Sr}$ was measured and found to be $0.710266(14) \quad(N=13$; confidence limit $=$ $95 \%)$ and the average value of ${ }^{143} \mathrm{Nd} /{ }^{144} \mathrm{Nd}$ through JNdi-1 standard was measured and found to be $0.5121050(58)(N=12$; confidence limit $=95 \%)($ see the results in table 2$)$.

Finally, data of the study were assessed by combining the information gathered through field operations, petrography and geochemical studies (major, trace and rare earth elements). 
Table 1. The results of chemical analysis of Peshtasar basalt of the Moghan sedimentary basin. The major elements (in wt\%) and the rare elements (in ppm) are reported.

\begin{tabular}{|c|c|c|c|c|c|c|c|c|c|}
\hline Sample & AH-1 & AH-3 & AH-DYKE & GRM-3 & GRM-6 & GRM-7 & GRM-11 & GRM-13 & GRM-15 \\
\hline $\mathrm{SiO}_{2}$ & 52.8 & 52.71 & 52.97 & 54.28 & 54.53 & 54.27 & 53.66 & 54.39 & 53.69 \\
\hline $\mathrm{TiO}_{2}$ & 0.4 & 0.62 & 0.44 & 1.05 & 1.03 & 1.06 & 1.06 & 1.05 & 1.07 \\
\hline $\mathrm{Al}_{2} \mathrm{O}_{3}$ & 17.76 & 16.75 & 18.94 & 15.94 & 16.79 & 16.71 & 16.8 & 16.47 & 17.21 \\
\hline $\mathrm{FeO}$ & 2.14 & 4.02 & 2.36 & 3.85 & 3.96 & 4.03 & 2.99 & 3.69 & 4.06 \\
\hline $\mathrm{Fe}_{2} \mathrm{O}_{3}$ & 2.21 & 3.5 & 2.32 & 2.91 & 2.93 & 2.99 & 2.09 & 2.67 & 2.85 \\
\hline $\mathrm{MnO}$ & 0.18 & 0.21 & 0.17 & 0.15 & 0.16 & 0.15 & 0.18 & 0.16 & 0.18 \\
\hline $\mathrm{MgO}$ & 1.21 & 3.51 & 1.46 & 4.17 & 3.73 & 3.87 & 3.9 & 3.78 & 3.9 \\
\hline $\mathrm{CaO}$ & 4.88 & 7.36 & 4.42 & 7.64 & 7.71 & 7.76 & 8.29 & 8.5 & 8.42 \\
\hline $\mathrm{Na}_{2} \mathrm{O}$ & 6.69 & 4.51 & 6.47 & 2.73 & 2.79 & 2.8 & 2.78 & 2.89 & 2.76 \\
\hline $\mathrm{K}_{2} \mathrm{O}$ & 3.28 & 2.15 & 2.87 & 3.52 & 3.23 & 3.24 & 3.04 & 3.19 & 3.05 \\
\hline $\mathrm{P}_{2} \mathrm{O}_{5}$ & 0.43 & 0.58 & 0.42 & 0.54 & 0.48 & 0.5 & 0.48 & 0.5 & 0.5 \\
\hline LOI & 7.55 & 3.55 & 6.55 & 2.56 & 1.99 & 1.89 & 1.72 & 2.01 & 1.57 \\
\hline Total & 99.53 & 99.47 & 99.39 & 99.34 & 99.33 & 99.27 & 96.99 & 99.3 & 99.26 \\
\hline $\mathrm{Ba}$ & 1198 & 1516 & 1153 & 800 & 1002 & 826 & 742 & 911 & 854 \\
\hline $\mathrm{Rb}$ & 65 & 16 & 55 & 74 & 61 & 66 & 66 & 63 & 54 \\
\hline $\mathrm{Sr}$ & 326.7 & 877.6 & 690.8 & 447.9 & 510.9 & 503.8 & 542.1 & 551.2 & 590.6 \\
\hline $\mathrm{Zr}$ & 128 & 119 & 129 & 185 & 178 & 179 & 163 & 167 & 171 \\
\hline $\mathrm{Nb}$ & 9.2 & 8.3 & 8.1 & 21.1 & 20.1 & 19.6 & 18.4 & 19.8 & 19.9 \\
\hline $\mathrm{Ni}$ & 1 & 9 & 3 & 45 & 49 & 47 & 54 & 50 & 55 \\
\hline $\mathrm{Co}$ & 9 & 19.6 & 11.2 & 20.9 & 21.6 & 21.8 & 22.8 & 22.2 & 23.6 \\
\hline $\mathrm{Zn}$ & 139 & 521 & 275 & 83 & 111 & 111 & 99 & 127 & 95 \\
\hline $\mathrm{Cr}$ & 8 & 31 & 11 & 113 & 116 & 137 & 156 & 146 & 159 \\
\hline $\mathrm{La}$ & 29 & 41 & 26 & 36 & 35 & 35 & 32 & 33 & 34 \\
\hline $\mathrm{Ce}$ & 62 & 98 & 63 & 80 & 86 & 78 & 71 & 79 & 78 \\
\hline $\operatorname{Pr}$ & 7.23 & 8.52 & 7.5 & 7.34 & 7.09 & 6.97 & 6.61 & 6.68 & 6.91 \\
\hline $\mathrm{Nd}$ & 26 & 32.9 & 27.8 & 27.7 & 27 & 26.3 & 25.3 & 25.5 & 26 \\
\hline $\mathrm{Sm}$ & 5.13 & 7.37 & 5.91 & 5.56 & 5.53 & 5.34 & 5.17 & 5.27 & 5.3 \\
\hline $\mathrm{Eu}$ & 1.87 & 2.45 & 2.05 & 1.65 & 1.64 & 1.61 & 1.58 & 1.6 & 1.65 \\
\hline Gd & 3.98 & 5.41 & 4.45 & 4.58 & 4.61 & 4.52 & 4.36 & 4.38 & 4.47 \\
\hline $\mathrm{Tb}$ & 0.51 & 0.74 & 0.6 & 0.68 & 0.7 & 0.68 & 0.65 & 0.66 & 0.67 \\
\hline Dy & 2.68 & 4.14 & 3.36 & 4.15 & 4.25 & 4.06 & 3.99 & 3.96 & 4.05 \\
\hline Er & 1.54 & 2.19 & 1.83 & 2.41 & 2.55 & 2.44 & 2.35 & 2.33 & 2.38 \\
\hline $\mathrm{Tm}$ & 0.22 & 0.28 & 0.26 & 0.33 & 0.36 & 0.34 & 0.33 & 0.32 & 0.33 \\
\hline $\mathrm{Yb}$ & 1.6 & 2.6 & 1.9 & 2.7 & 2.7 & 2.8 & 2.7 & 2.6 & 2.7 \\
\hline $\mathrm{Lu}$ & 0.23 & 0.29 & 0.27 & 0.34 & 0.35 & 0.34 & 0.33 & 0.33 & 0.33 \\
\hline $\mathrm{Y}$ & 13.1 & 19.7 & 16 & 21.3 & 21.9 & 20.9 & 20.3 & 20.5 & 20.9 \\
\hline Cs & 3.7 & 2.3 & 4.2 & 0.7 & 1 & 0.8 & 0.9 & 1.1 & 0.7 \\
\hline $\mathrm{Ta}$ & 0.89 & 1.09 & 0.84 & 1.62 & 1.61 & 1.46 & 1.36 & 1.61 & 1.49 \\
\hline Hf & 2.66 & 2.71 & 3.02 & 4.23 & 4.24 & 4.03 & 3.76 & 3.77 & 3.93 \\
\hline Th & 10.56 & 9.14 & 10.14 & 10.67 & 10.53 & 10.17 & 9.23 & 9.2 & 9.23 \\
\hline $\mathrm{V}$ & 76 & 193 & 119 & 170 & 174 & 182 & 181 & 176 & 179 \\
\hline $\mathrm{Pb}$ & 63 & 124 & 135 & 22 & 22 & 410 & 43 & 42 & 107 \\
\hline $\mathrm{U}$ & 2.6 & 2.5 & 2.1 & 2.9 & 2.81 & 2.7 & 2.4 & 2.6 & 2.6 \\
\hline S.I & 7.90 & 20.24 & 9.58 & 24.69 & 22.82 & 23.27 & 26.73 & 23.69 & 23.88 \\
\hline $\mathrm{Mg} \#$ & 36.12 & 46.61 & 38.22 & 52.00 & 48.50 & 48.99 & 56.60 & 50.60 & 48.99 \\
\hline $\mathrm{Eu} / \mathrm{Eu}^{*}$ & 1.22 & 1.14 & 1.18 & 0.97 & 0.97 & 0.98 & 0.99 & 0.99 & 1.01 \\
\hline$(\mathrm{La} / \mathrm{Sm})_{N}$ & 3.10 & 3.05 & 2.41 & 3.55 & 3.47 & 3.59 & 3.39 & 3.43 & 3.52 \\
\hline$(\mathrm{La} / \mathrm{Yb})_{N}$ & 10.98 & 9.56 & 8.29 & 8.08 & 7.86 & 7.58 & 7.18 & 7.69 & 7.63 \\
\hline$(\mathrm{Tb} / \mathrm{Yb})_{N}$ & 1.36 & 1.21 & 1.34 & 1.07 & 1.10 & 1.03 & 1.02 & 1.08 & 1.06 \\
\hline
\end{tabular}


Table 1. (Continued.)

\begin{tabular}{|c|c|c|c|c|c|c|c|c|}
\hline Sample & GRM-19 & ML-2 & SA-2 & SH-2 & SH-11 & TZ-2 & TZ-4 & TZ-5 \\
\hline $\mathrm{SiO}_{2}$ & 54.58 & 56.99 & 57.28 & 54.2 & 55.07 & 56.01 & 52.78 & 53.41 \\
\hline $\mathrm{TiO}_{2}$ & 1.07 & 0.86 & 0.86 & 0.42 & 0.44 & 0.66 & 0.93 & 1.02 \\
\hline $\mathrm{Al}_{2} \mathrm{O}_{3}$ & 17.01 & 17.73 & 17.71 & 18.38 & 20.14 & 19.66 & 16.36 & 16.15 \\
\hline $\mathrm{FeO}$ & 3.7 & 2.83 & 2.73 & 2.05 & 2.29 & 2.48 & 4.12 & 4.04 \\
\hline $\mathrm{Fe}_{2} \mathrm{O}_{3}$ & 2.73 & 2.82 & 2.78 & 1.98 & 2.23 & 2.23 & 2.81 & 3.42 \\
\hline $\mathrm{MnO}$ & 0.17 & 0.15 & 0.13 & 0.13 & 0.13 & 0.1 & 0.15 & 0.15 \\
\hline $\mathrm{MgO}$ & 3.81 & 2.39 & 2.06 & 1.38 & 2.45 & 2.08 & 5.87 & 4.86 \\
\hline $\mathrm{CaO}$ & 8.13 & 4.73 & 5.18 & 6.75 & 4.83 & 6.26 & 7.24 & 7.97 \\
\hline $\mathrm{Na}_{2} \mathrm{O}$ & 2.86 & 3.34 & 3.44 & 3.83 & 2.84 & 3.44 & 2.56 & 2.68 \\
\hline $\mathrm{K}_{2} \mathrm{O}$ & 3.19 & 5.37 & 5.34 & 5.32 & 5.71 & 4.38 & 3.05 & 3.03 \\
\hline $\mathrm{P}_{2} \mathrm{O}_{5}$ & 0.48 & 0.72 & 0.72 & 0.45 & 0.45 & 0.57 & 0.49 & 0.45 \\
\hline LOI & 1.64 & 1.53 & 1.25 & 4.31 & 2.77 & 1.62 & 2.98 & 1.97 \\
\hline Total & 99.37 & 99.46 & 99.48 & 99.2 & 99.35 & 99.49 & 99.34 & 99.15 \\
\hline $\mathrm{Ba}$ & 749 & 1128 & 1090 & 1505 & 1319 & 1209 & 898 & 959 \\
\hline $\mathrm{Rb}$ & 65 & 94 & 118 & 72 & 90 & 78 & 55 & 68 \\
\hline $\mathrm{Sr}$ & 528.3 & 458.3 & 484.4 & 1067.7 & 1279.9 & 633.9 & 497.2 & 511.6 \\
\hline $\mathrm{Zr}$ & 168 & 177 & 173 & 138 & 141 & 128 & 148 & 155 \\
\hline $\mathrm{Nb}$ & 19.4 & 16.4 & 16.8 & 10.8 & 11.3 & 13.4 & 17.7 & 20 \\
\hline $\mathrm{Ni}$ & 54 & 9 & 9 & 3 & 2 & 14 & 69 & 61 \\
\hline $\mathrm{Co}$ & 23.8 & 11.4 & 11.3 & 11.4 & 10.7 & 11.9 & 23 & 23.7 \\
\hline $\mathrm{Zn}$ & 118 & 175 & 128 & 87 & 155 & 81 & 77 & 87 \\
\hline $\mathrm{Cr}$ & 150 & 19 & 21 & 9 & 15 & 29 & 153 & 161 \\
\hline $\mathrm{La}$ & 33 & 33 & 35 & 39 & 40 & 25 & 31 & 31 \\
\hline $\mathrm{Ce}$ & 72 & 78 & 79 & 85 & 85 & 69 & 76 & 77 \\
\hline $\operatorname{Pr}$ & 6.81 & 7.27 & 7.61 & 7.58 & 7.95 & 5.54 & 6.91 & 6.94 \\
\hline $\mathrm{Nd}$ & 26 & 27.2 & 28.7 & 28 & 28.9 & 21.1 & 26.7 & 26.2 \\
\hline $\mathrm{Sm}$ & 5.27 & 5.68 & 5.91 & 6.11 & 6.04 & 4.52 & 5.59 & 5.52 \\
\hline $\mathrm{Eu}$ & 1.68 & 1.71 & 1.78 & 2.05 & 2.06 & 1.61 & 1.76 & 1.71 \\
\hline $\mathrm{Gd}$ & 4.45 & 4.56 & 4.56 & 4.43 & 4.46 & 3.78 & 4.69 & 4.6 \\
\hline $\mathrm{Tb}$ & 0.67 & 0.65 & 0.69 & 0.61 & 0.61 & 0.54 & 0.7 & 0.68 \\
\hline Dy & 4.06 & 3.94 & 4.15 & 3.47 & 3.46 & 3.2 & 4.27 & 4.19 \\
\hline Er & 2.4 & 2.39 & 2.49 & 1.97 & 1.94 & 1.9 & 2.45 & 2.51 \\
\hline $\mathrm{Tm}$ & 0.33 & 0.34 & 0.35 & 0.28 & 0.28 & 0.27 & 0.35 & 0.33 \\
\hline $\mathrm{Yb}$ & 2.7 & 2.7 & 2.7 & 2 & 2 & 1.9 & 2.5 & 2.5 \\
\hline $\mathrm{Lu}$ & 0.32 & 0.34 & 0.36 & 0.29 & 0.29 & 0.28 & 0.34 & 0.34 \\
\hline $\mathrm{Y}$ & 20.9 & 20.7 & 21.6 & 16.8 & 16.6 & 16 & 21.9 & 21.6 \\
\hline Cs & 0.8 & 1.6 & 2.5 & 3.5 & 3.1 & 1.3 & 0.7 & 1.4 \\
\hline $\mathrm{Ta}$ & 1.4 & 1.22 & 1.25 & 0.95 & 0.94 & 1.13 & 1.44 & 1.53 \\
\hline $\mathrm{Hf}$ & 3.95 & 4.02 & 4.09 & 3.38 & 3.21 & 3.27 & 3.74 & 3.68 \\
\hline Th & 9.39 & 9.52 & 9.75 & 13.05 & 13.17 & 7.45 & 9.13 & 9.56 \\
\hline $\mathrm{V}$ & 186 & 140 & 140 & 107 & 109 & 113 & 172 & 176 \\
\hline $\mathrm{Pb}$ & 24 & 25 & 21 & 38 & 42 & 74 & 17 & 812 \\
\hline $\mathrm{U}$ & 2.6 & 3.07 & 3.1 & 4.3 & 3.9 & 2.1 & 2 & 2.2 \\
\hline S.I & 23.79 & 14.51 & 12.82 & 9.61 & 16.02 & 14.46 & 32.38 & 27.48 \\
\hline $\mathrm{Mg} \#$ & 50.73 & 45.79 & 43.01 & 40.23 & 51.69 & 45.61 & 58.76 & 54.61 \\
\hline $\mathrm{Eu} / \mathrm{Eu}^{*}$ & 1.04 & 1.00 & 1.01 & 1.15 & 1.16 & 1.16 & 1.03 & 1.01 \\
\hline$(\mathrm{La} / \mathrm{Sm})_{N}$ & 3.43 & 3.19 & 3.25 & 3.50 & 3.63 & 3.03 & 3.04 & 3.08 \\
\hline$(\mathrm{La} / \mathrm{Yb})_{N}$ & 7.41 & 7.41 & 7.86 & 11.82 & 12.12 & 7.97 & 7.52 & 7.52 \\
\hline$(\mathrm{Tb} / \mathrm{Yb})_{N}$ & 1.06 & 1.02 & 1.09 & 1.30 & 1.30 & 1.21 & 1.19 & 1.16 \\
\hline
\end{tabular}


63 Page 8 of 22

J. Earth Syst. Sci. (2019) 128:63

Table 1. (Continued.)

\begin{tabular}{|c|c|c|c|c|c|c|c|c|}
\hline Sample & KL-1 & KL-2 & KL-3 & KL-4 & KL-5 & KL-6 & KL-7 & KL-8 \\
\hline $\mathrm{SiO}_{2}$ & 51.7 & 52.46 & 50.71 & 49.98 & 52.47 & 51.14 & 49.44 & 50.78 \\
\hline $\mathrm{TiO}_{2}$ & 0.48 & 0.52 & 0.61 & 0.72 & 0.54 & 0.49 & 0.68 & 0.62 \\
\hline $\mathrm{Al}_{2} \mathrm{O}_{3}$ & 17.14 & 16.98 & 17.41 & 17.16 & 16.78 & 16.88 & 17.21 & 17.86 \\
\hline $\mathrm{FeO}$ & 3.73 & 3.94 & 4.04 & 4.33 & 3.68 & 3.53 & 4.6 & 3.76 \\
\hline $\mathrm{Fe}_{2} \mathrm{O}_{3}$ & 3.58 & 4 & 3.73 & 3.48 & 3.39 & 3.74 & 3.68 & 3.1 \\
\hline $\mathrm{MnO}$ & 0.19 & 0.24 & 0.26 & 0.28 & 0.17 & 0.2 & 0.27 & 0.24 \\
\hline $\mathrm{MgO}$ & 3.84 & 2.81 & 3.44 & 4.96 & 3.61 & 3.87 & 4.71 & 4.04 \\
\hline $\mathrm{CaO}$ & 6.81 & 6.85 & 6.94 & 7.12 & 6.88 & 6.84 & 8.85 & 8.74 \\
\hline $\mathrm{Na}_{2} \mathrm{O}$ & 5.86 & 6.14 & 5.71 & 4.94 & 5.61 & 6.72 & 4.91 & 5.21 \\
\hline $\mathrm{K}_{2} \mathrm{O}$ & 3.64 & 3.66 & 3.48 & 2.84 & 3.34 & 3.94 & 2.88 & 2.64 \\
\hline $\mathrm{P}_{2} \mathrm{O}_{5}$ & 0.44 & 0.56 & 0.52 & 0.61 & 0.55 & 0.48 & 0.62 & 0.52 \\
\hline LOI & 1.86 & 1.36 & 2.31 & 2.15 & 2.02 & 1.44 & 1.52 & 1.82 \\
\hline Total & 99.27 & 99.52 & 99.16 & 98.57 & 99.04 & 99.27 & 99.37 & 99.33 \\
\hline $\mathrm{Ba}$ & 1162 & 1159 & 1189 & 1021 & 1194 & 926 & 947 & 1014 \\
\hline $\mathrm{Rb}$ & 66 & 61 & 60 & 54 & 48 & 51 & 54 & 53 \\
\hline $\mathrm{Sr}$ & 336 & 354 & 477 & 645 & 372 & 482 & 686 & 598 \\
\hline $\mathrm{Zr}$ & 126 & 132 & 117 & 106 & 139 & 127 & 107 & 112 \\
\hline $\mathrm{Nb}$ & 9.4 & 9.2 & 18.6 & 19.4 & 10.1 & 11.2 & 17.4 & 18.2 \\
\hline $\mathrm{Ni}$ & 3 & 5 & 7 & 10 & 9 & 11 & 14 & 6 \\
\hline Co & 11 & 18 & 16 & 21 & 14 & 22 & 26 & 20 \\
\hline $\mathrm{Zn}$ & 97 & 106 & 112 & 78 & 112 & 131 & 102 & 97 \\
\hline $\mathrm{Cr}$ & 9 & 12 & 14 & 22 & 17 & 24 & 20 & 19 \\
\hline La & 29.1 & 32.6 & 31.7 & 26.1 & 31.4 & 25.2 & 26.7 & 28.1 \\
\hline $\mathrm{Ce}$ & 56 & 69 & 51 & 47 & 58 & 61 & 46 & 48 \\
\hline $\operatorname{Pr}$ & 7.21 & 7.25 & 6.82 & 6.94 & 7.14 & 7.26 & 6.91 & 6.88 \\
\hline $\mathrm{Nd}$ & 26.2 & 29.4 & 27.1 & 24.9 & 27.3 & 31.2 & 25.4 & 26.2 \\
\hline $\mathrm{Sm}$ & 5.11 & 5.14 & 5.31 & 5.42 & 5.91 & 5.81 & 5.17 & 5.35 \\
\hline $\mathrm{Eu}$ & 1.88 & 1.72 & 2.44 & 2.72 & 1.92 & 1.84 & 2.51 & 2.62 \\
\hline $\mathrm{Gd}$ & 3.82 & 4.36 & 4.71 & 3.76 & 4.04 & 3.92 & 4.17 & 4.34 \\
\hline $\mathrm{Tb}$ & 0.54 & 0.56 & 0.62 & 0.66 & 0.52 & 0.53 & 0.61 & 0.58 \\
\hline Dy & 2.68 & 3.11 & 3.21 & 3.74 & 2.61 & 2.74 & 3.68 & 4.01 \\
\hline Er & 1.61 & 1.72 & 1.84 & 2.51 & 2.08 & 1.92 & 2.48 & 2.31 \\
\hline $\mathrm{Tm}$ & 0.24 & 0.26 & 0.33 & 0.31 & 0.23 & 0.28 & 0.35 & 0.32 \\
\hline $\mathrm{Yb}$ & 1.81 & 2.14 & 2.61 & 2.77 & 2.86 & 1.74 & 2.77 & 2.44 \\
\hline $\mathrm{Lu}$ & 0.24 & 0.26 & 0.23 & 0.34 & 0.23 & 0.25 & 0.33 & 0.3 \\
\hline $\mathrm{Y}$ & 16.12 & 14.16 & 21.14 & 27.17 & 17.14 & 17.81 & 24.14 & 23.14 \\
\hline Cs & 3.4 & 3.7 & 2.6 & 2.4 & 3.4 & 3.5 & 2.8 & 2.7 \\
\hline $\mathrm{Ta}$ & 0.88 & 0.92 & 1.08 & 1.42 & 1.02 & 1.12 & 1.36 & 1.32 \\
\hline $\mathrm{Hf}$ & 2.71 & 2.66 & 2.81 & 3.04 & 4.02 & 3.12 & 2.94 & 3.14 \\
\hline Th & 24.86 & 25.14 & 23.12 & 20.14 & 26.77 & 24.41 & 20.02 & 21.14 \\
\hline V & 82 & 74 & 114 & 144 & 92 & 106 & 145 & 132 \\
\hline $\mathrm{Pb}$ & 68 & 69 & 71 & 54 & 94 & 81 & 74 & 82 \\
\hline $\mathrm{U}$ & 5.44 & 6.14 & 4.98 & 5.12 & 6.31 & 5.41 & 4.86 & 5.02 \\
\hline S.I & 18.92 & 13.95 & 17.18 & 24.55 & 18.71 & 18.06 & 23.07 & 21.91 \\
\hline $\mathrm{Mg} \#$ & 50.73 & 41.63 & 45.99 & 53.39 & 49.52 & 52.30 & 50.59 & 51.79 \\
\hline $\mathrm{Eu} / \mathrm{Eu}^{*}$ & 1.25 & 1.09 & 1.47 & 1.75 & 1.14 & 1.11 & 1.61 & 1.62 \\
\hline$(\mathrm{La} / \mathrm{Sm})_{N}$ & 3.12 & 3.48 & 3.27 & 2.64 & 2.91 & 2.38 & 2.83 & 2.88 \\
\hline$(\mathrm{La} / \mathrm{Yb})_{N}$ & 9.74 & 9.23 & 7.36 & 5.71 & 6.65 & 8.78 & 5.84 & 6.98 \\
\hline$(\mathrm{Tb} / \mathrm{Yb})_{N}$ & 1.27 & 1.11 & 1.01 & 1.01 & 0.77 & 1.30 & 0.94 & 1.01 \\
\hline
\end{tabular}


Table 2. The results of Sr and Nd isotope analysis of the studied samples.

\begin{tabular}{|c|c|c|c|c|c|}
\hline Sample & GRM-6 & GRM-19 & $\mathrm{SH}-2$ & SH-11 & TZ-5 \\
\hline Lithology & Basalt & Basalt & Tephrite & Basalt & Basalt \\
\hline Analysis conc. & ICPMS & ICPMS & ICPMS & ICPMS & ICPMS \\
\hline $\mathrm{Sr}(\mathrm{ppm})$ & 511 & 528 & 1068 & 1280 & 512 \\
\hline Rb (ppm) & 61 & 65 & 72 & 90 & 68 \\
\hline${ }^{87} \mathrm{Rb} /{ }^{86} \mathrm{Sr}$ & 0.345 & 0.356 & 0.195 & 0.203 & 0.384 \\
\hline Erro (2s) & 0.010 & 0.010 & 0.006 & 0.006 & 0.011 \\
\hline${ }^{87} \mathrm{Sr} /{ }^{86} \mathrm{Sr}$ & 0.705387 & 0.705155 & 0.704759 & 0.704846 & 0.705238 \\
\hline Erro $(2 \mathrm{~s})$ & 0.000025 & 0.000020 & 0.000021 & 0.000017 & 0.000021 \\
\hline Nd (ppm) & 27.0 & 26.0 & 28.0 & 28.9 & 26.2 \\
\hline Sm (ppm) & 5.53 & 5.27 & 6.11 & 6.04 & 5.52 \\
\hline${ }^{147} \mathrm{Sm} /{ }^{144} \mathrm{Nd}$ & 0.124 & 0.123 & 0.132 & 0.126 & 0.127 \\
\hline Erro $(2 s)$ & 0.007 & 0.007 & 0.007 & 0.007 & 0.007 \\
\hline${ }^{143} \mathrm{Nd} /{ }^{144} \mathrm{Nd}$ & 0.512673 & 0.512676 & 0.512782 & 0.512776 & 0.512650 \\
\hline Erro $(2 \mathrm{~s})$ & 0.000019 & 0.000024 & 0.000013 & 0.000016 & 0.000016 \\
\hline${ }^{87} \mathrm{Sr} /{ }^{86} \mathrm{Sr}(35)$ & 0.705218 & 0.704981 & 0.704664 & 0.704747 & 0.705050 \\
\hline $\operatorname{SrUR}(35)$ & 0.704460 & 0.704460 & 0.704460 & 0.704460 & 0.704460 \\
\hline$\varepsilon \operatorname{Sr}(35)$ & 10.76 & 7.40 & 2.90 & 4.08 & 8.38 \\
\hline${ }^{143} \mathrm{Nd} /{ }^{144} \mathrm{Nd}(35)$ & 0.512644 & 0.512648 & 0.512752 & 0.512747 & 0.512621 \\
\hline NdChur(35) & 0.512593 & 0.512593 & 0.512593 & 0.512593 & 0.512593 \\
\hline$\varepsilon \mathrm{Nd}(35)$ & 1.00 & 1.06 & 3.09 & 3.00 & 0.54 \\
\hline
\end{tabular}

\section{Petrography}

Peshtasar basalts depict lithologically different compositions throughout the basin. The eastern part of the Moghan basin has basaltic lithology with the pillow structure and gabbroic rocks. The main minerals of basalts are clinopyroxene, plagioclase and olivine. Besides, plagioclase microcrystals along with clinopyroxene and glass (rich/ poor in the glass with different amounts) make up the groundmass. The dominant texture of these rocks changes between hyalomicrolitic porphyry (figure 4A) and microlitic porphyry (figure 4B). The glomeroporphyric texture derived from the accumulation of clinopyroxenes and idingisitised olivine is another texture that is observed (figure 4C). Plagioclase phenocrysts in some specimens have sieve texture with a growth margin (figure 4D). Euhedral olivine phenocryst has been altered to iddingesite, carbonate, bulengite and anthophyllite (figure 4E); they are sometimes seen as the inclusion within clinopyroxenes. The middle part of the basin has basaltic andesite, megaporphyric andesite, tephrite and tephritic dykes. The main minerals are clinopyroxene, plagioclase, olivine and leucite, while microcrystalline plagioclase along with pyroxene and glass form the groundmass. Moreover, titanomagnetite and apatite are the accessory minerals in these rocks. Zeolite, calcite, iddingesite and kaolinite are secondary minerals. The dominant textures of these rocks in thin section are hyalomicrolitic porphyry, hyaloporphyric (figure $4 \mathrm{~F}$ ) and microlitic porphyry. Lithophysa and amygdaloid are subordinate textures. Analcime is an alteration product of leucite. The presence of mafic magma cells, as well as the presence of glasses of two different refractive indices, is the evidence of magma mixing in these rocks (figure $4 \mathrm{G}$ ). Other rock types in the area are volcanic breccia with breccia texture and agglomerate. The western part of the basin is predominantly composed of basaltic andesite, leucite tephrite, andesite and microgabbroic dykes. Basaltic flows have pillow structures. The main minerals are pyroxene, plagioclase, olivine and leucite, while the groundmass is made of microcrystalline plagioclase along with pyroxene and glass. The secondary minerals are titano-magnetite and apatite. The dominant texture of these rocks is hyalomicrolitic porphyry and microlitic porphyry. As subordinate textures, lithophysa, amygdaloid and glomeroporphyric textures are formed as a result of the clinopyroxene accumulation. Since plagioclase phenocrysts with sieve texture are surrounded with leucite, they have been crystallised first. Besides, they are crushed and altered in some samples. The leucite crystals are euhedral (figure $4 \mathrm{H}$ ) and have been altered to analcime in some samples (figure 4I). 

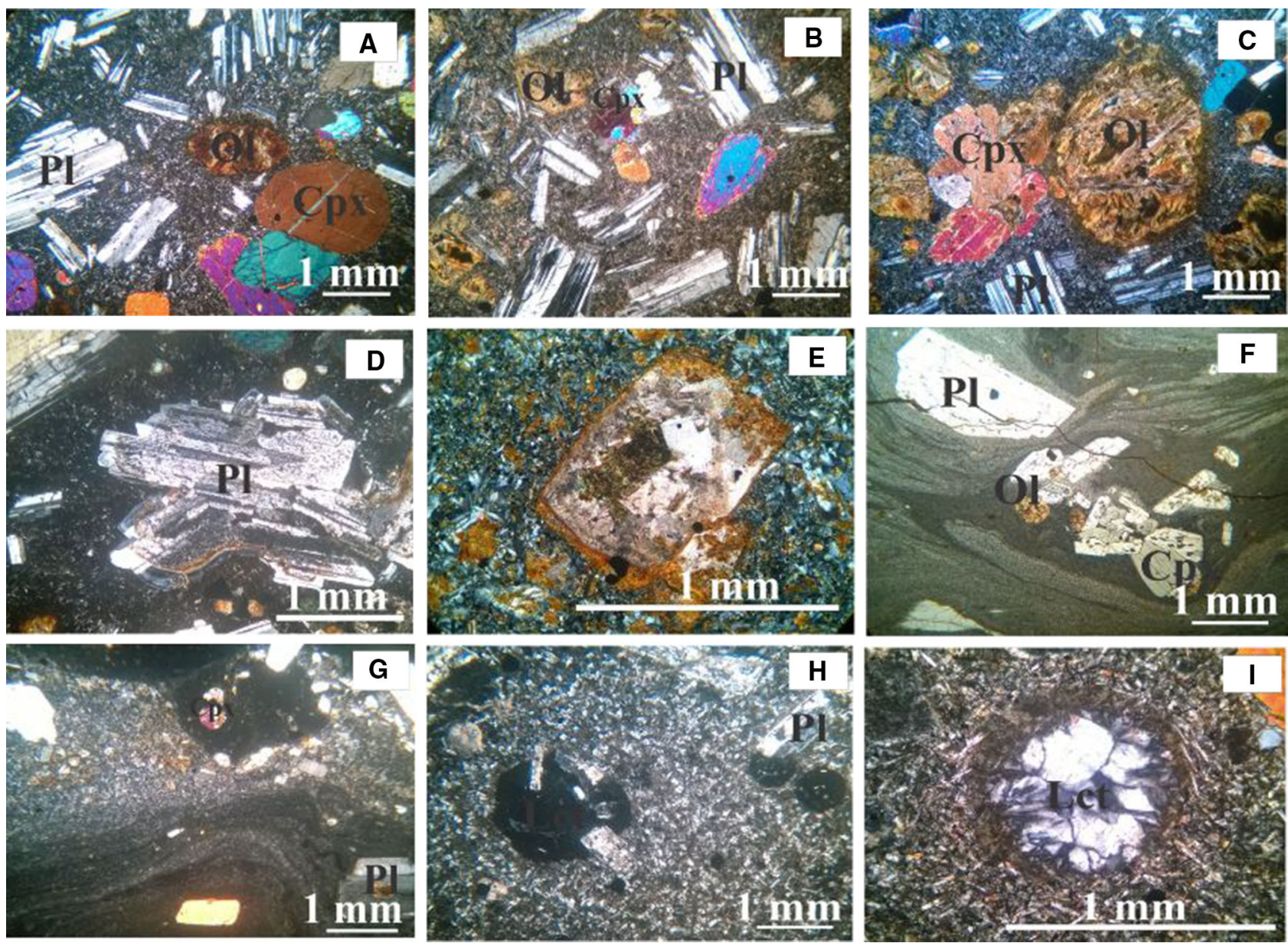

Figure 4. (A) Hyalomicrolitic porphyry texture and plagioclase, clinopyroxene and idingisitised olivine phenocrysts in basalt XPL. (B) Microlitic porphyry texture and plagioclase, clinopyroxene and idingisitised olivine crystals in basalt XPL. (C) Glomeroporphyric texture resulting from accumulation of clinopyroxene and idingisitised olivine in basalt XPL. (D) Sieve texture with a growth margin of plagioclase phenocrystal in basalt XPL. (E) Olivine alteration to iddingesite, carbonate, bulengite and anthophyllite in basalt XPL. (F) Hyaloporphyric texture and olivine, plagioclase and clinopyroxene phenocrysts in basalt PPL. (G) Magma mixing with two different textures in basalt XPL. (H) Euhedral leucite crystal in leucite tephrite XPL. (I) Pseudomorph leucite crystal by analcime in leucite tephrite XPL. The mineral abbreviations are adopted from Kretz (1983).

\section{Results and discussion}

\subsection{Geochemistry}

\subsubsection{Major elements}

The results of chemical and isotopic analyses of Peshtasar basalts of the Moghan sedimentary basin are presented in tables 1 and $2 . \mathrm{SiO}_{2}$ content ranges from $49.44 \%$ to $57.28 \%$ that is similar to basalt and basaltic andesites. In basalts the amounts of $\mathrm{TiO}_{2}, \mathrm{FeO}, \mathrm{Fe}_{2} \mathrm{O}_{3}$ and $\mathrm{MgO}$ oxides are $0.40-1.07,2.05-4.60,1.98-4$ and $1.21-5.87 \mathrm{wt} \%$, respectively. Variations of some major elements against $\mathrm{SiO}_{2}$ are shown for basaltic rocks. As $\mathrm{SiO}_{2}$ increases, $\mathrm{TiO}_{2}, \mathrm{FeOt}$ and $\mathrm{MgO}$ decreases. This fact is representative of fractional crystallisation of clinopyroxene minerals during the crystallisation of magma (Gourgaud and Vincent 2004) (figure 5). As incompatible elements, $\mathrm{Na}_{2} \mathrm{O}$ and $\mathrm{K}_{2} \mathrm{O}$ display an increasing trend with increasing $\mathrm{SiO}_{2}$ (figure 5). $\mathrm{P}_{2} \mathrm{O}_{5}$ shows an increasing trend with increasing $\mathrm{SiO}_{2}$, which is because of the incompatibility of phosphor in the early stages of basic magma fractionation and apatite crystallisation in the final stages of fractional crystallisation (figure 5). The high $\mathrm{Al}_{2} \mathrm{O}_{3}$ content in basalts reflects the crystallisation of mafic minerals from parental magma (primary) at relatively high pressures (Yoder Jr and Tilley 1962; Gust and Perfit 1987), leading to not only the concentration of aluminium in the remaining melt, but also the crystallisation of 

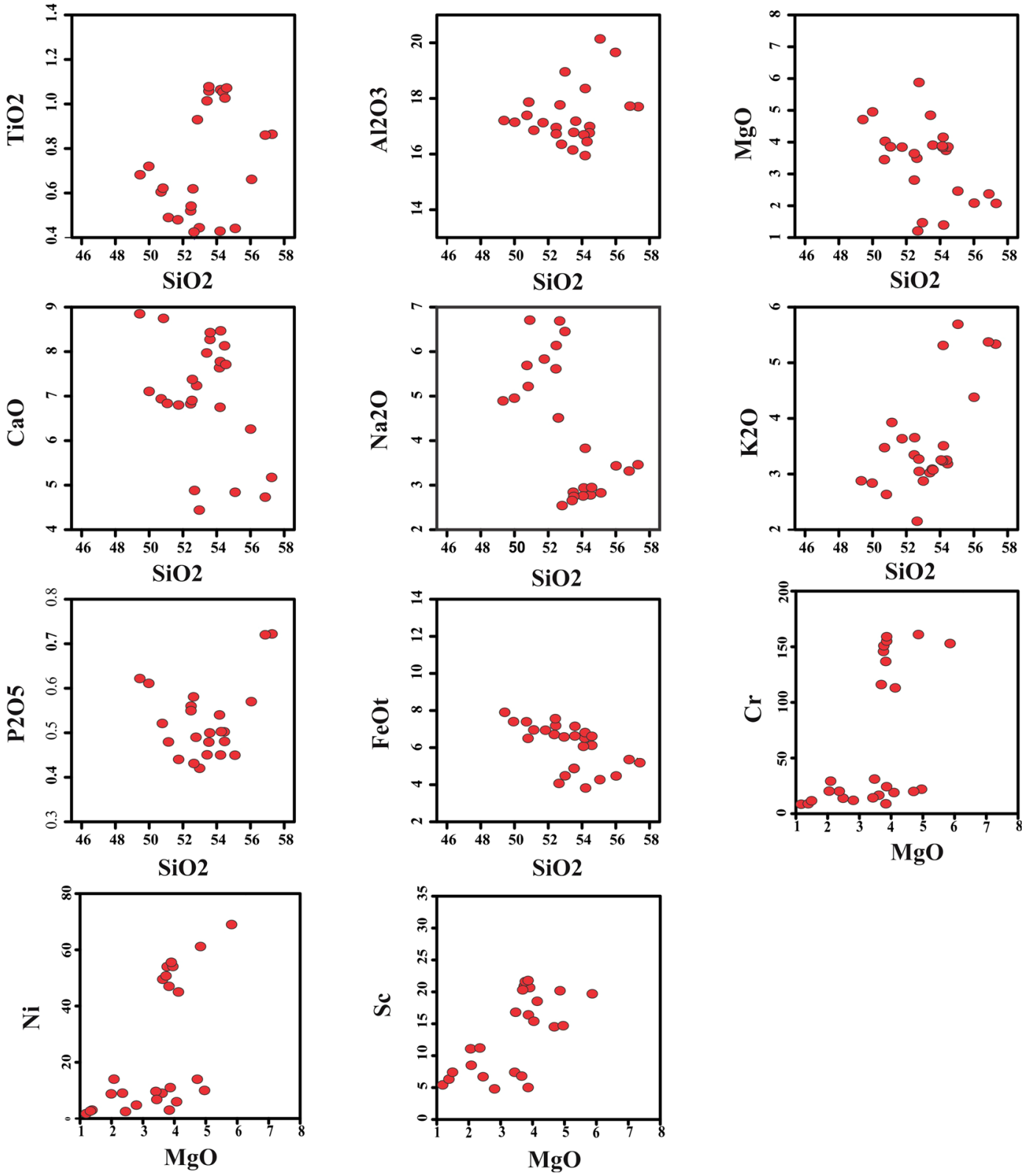

Figure 5. Major oxides and rare elements variation diagrams vs. $\mathrm{SiO}_{2}$ and $\mathrm{MgO}$.

plagioclase at lower pressures. As $\mathrm{SiO}_{2}$ increases, the amount of $\mathrm{CaO}$ in the samples decreases slightly - this can be attributed to the evolution of the plagioclase from calcic to sodic during the fractional crystallisation of the magma (figure 5).

\subsubsection{Minor and trace elements}

The amounts of $\mathrm{Ni}, \mathrm{Cr}$ and $\mathrm{Sc}$ are 1-69, 8-161, and 4.8-21.6 ppm, respectively. As $\mathrm{Mg}$ decreases and crystallisation progresses, $\mathrm{Ni}, \mathrm{Cr}$ and $\mathrm{Sc}$ values decrease, which can be attributed to the fractional crystallisation of olivine and clinopyroxene minerals. Thus, as $\mathrm{MgO}$ decreases, $\mathrm{Ni}$ is absorbed by olivine, while $\mathrm{Cr}$ and $\mathrm{Sc}$ are absorbed by clinopyroxene. The aluminium content of the samples is high, about $17.35 \%$. Primary magmas, which are in equilibrium with the upper mantle mineralogical composition, must have a magnesium number above 70 , nickel content greater than 1400-1500 ppm, chromium more than $1000 \mathrm{ppm}$ and silicon oxide less than $50 \mathrm{wt} \%$ (Gaetani 2004). However, if the basic magma is derived from the metasomatic mantle instead of a normal mantle, these criteria will not be applicable (Wilson 1989). Moreover, considering an increase in 
magma evolution, the magnesium number reduces. The analysed samples with an average magnesium number of 48.52 , the mean chromium of $62.84 \mathrm{ppm}$ and average $23.96 \mathrm{ppm}$ of nickel are not in equilibrium with the upper mantle. The value of $\mathrm{Mg} \#$ used for the detection of primary magma from fractionated magma (Jenner et al. 1987; Downes et al. 1995) varies from 36.12 to 58.76 in the studied rocks and has an average content of 48.52 .

The binary diagrams including Sr-Ba, (Pearce and Norry 1979; Kim and Cho 2003) (figure 6A), $\mathrm{Zr}-\mathrm{Y}$ (Irvine and Baragar 1971) (figure 6B) and $\mathrm{SiO}_{2}-\mathrm{Al}_{2} \mathrm{O}_{3} / \mathrm{CaO}$ (Zhu et al. 2007) (figure 6C) have been used to characterise the most important fractionated minerals from magmas. Clinopyroxene separation affects $\mathrm{Sr}$ and $\mathrm{Ba}$ ratio, whereas the ratio of $\mathrm{Zr}$ and $\mathrm{Y}$ is controlled by plagioclase separation. The $\mathrm{SiO}_{2}-\mathrm{Al}_{2} \mathrm{O}_{3} / \mathrm{CaO}$ diagram shows clinopyroxene separation in basalts. This is observed in petrographical studies.

In TAS diagram (Le Bas et al. 1986) (figure 7) the samples are plotted in the field of basaltic trachy-andesite, trachy-andesite and tephriphonolite. In $\mathrm{K}_{2} \mathrm{O}-\mathrm{SiO}_{2}$ (Le Maitre 2002) (figure 8A) and Th-Co diagrams (Hastie et al. 2007) (figure 8B) the samples plot in high potassium calc-alkaline and shoshonitic fields. The position of the samples in the (Shand 1943) diagram indicates the meta-aluminous nature of rocks and only one sample plots in peraluminous field (figure $8 \mathrm{C}$ ). In $\mathrm{TiO}_{2}$ vs. $\mathrm{Ti} / \mathrm{Y}$ diagram (Zhou et al. 2008) basaltic samples are located in low titanium fields (figure 8D).

\subsubsection{REE spider diagrams}

Chondrite-normalised multivariate charts have been used to investigate and evaluate the trace and rare earth elements. According to the chondritenormalised spider diagram (Thompson 1982), basaltic samples from the Moghan basin are enriched in LILEs (Ba, Rb, Th, K) and depleted in HFSEs (Ti, Yb, Y) (figure 9A). Enrichment of LILE is either inherited from the mantle origin, which has been already metasomatised by combining subduction areas, or resulted from crustal arc contamination (Liu and Liu 2014). Studying the variation of REEs based on the chondrite-normalised spider diagram (Boynton 1984), the LREEs are more enriched than HREEs (figure 9B). The REE pattern in the rare earth element diagram depicts a low negative gradient. $(\mathrm{La} / \mathrm{Yb})_{N}$ varies between 5.71 and 12.12. The amount of $\left(\mathrm{Eu} / \mathrm{Eu}^{*}\right)$ calculated
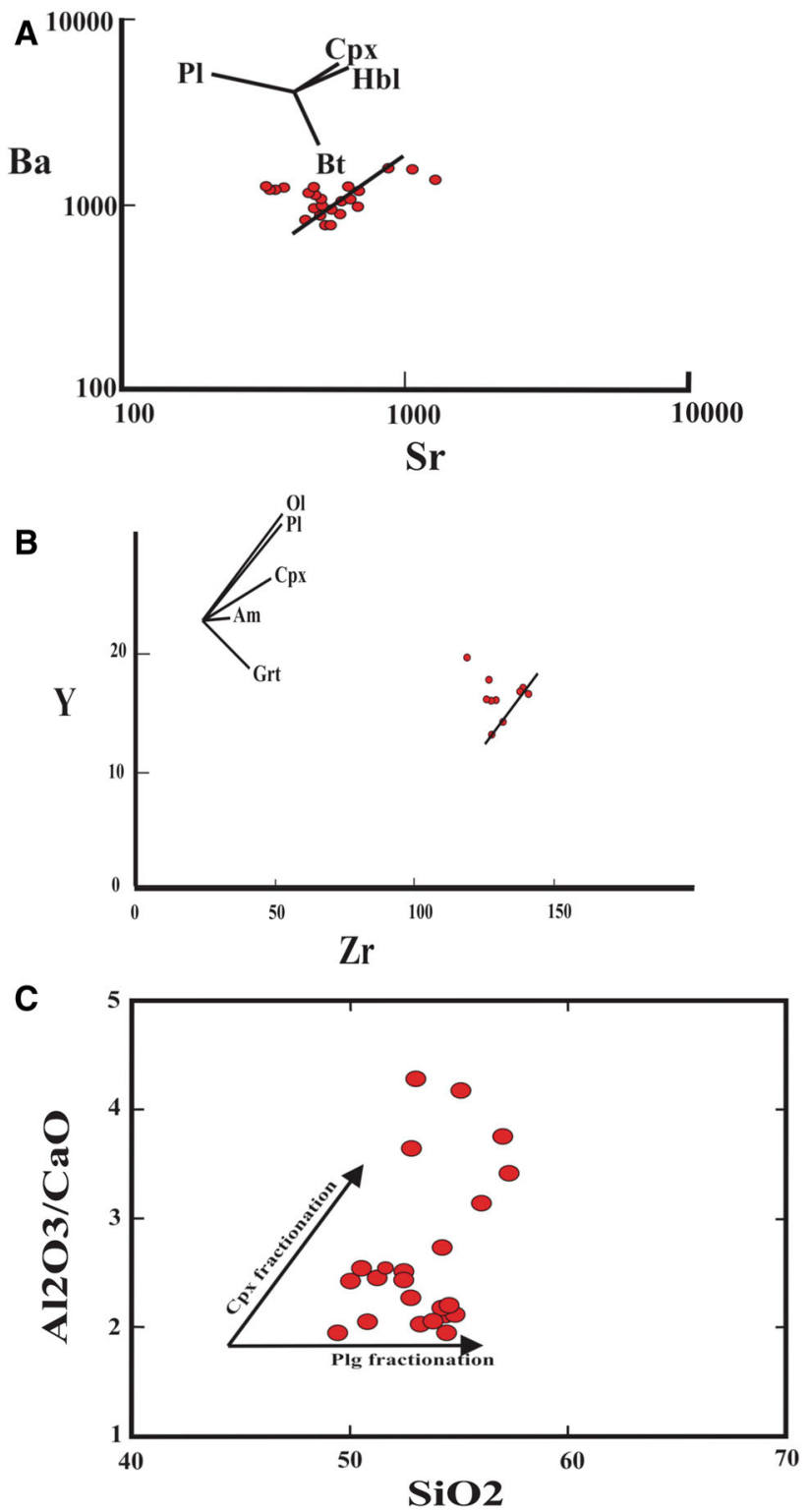

Figure 6. Characteristic diagram of the main fractionated minerals from parental magma. (A) Ba vs. Sr diagram (Pearce and Norry 1979; Kim and Cho 2003) indicates clinopyroxene crystallisation. (B) Y vs. Zr diagram (Irvine and Baragar 1971) indicates plagioclase crystallisation. (C) $\mathrm{Al}_{2} \mathrm{O}_{3} / \mathrm{CaO}$ vs. $\mathrm{SiO}_{2}$ (Zhu et al. 2007) indicates clinopyroxene crystallisation.

in the basalts fluctuates between 0.97 and 1.75. Besides, its mean value is 1.16 , which represents the positive anomaly of $\mathrm{Eu}$ in basalts, indicating frequency of calcic plagioclase in the rocks and low oxygen fugacity. In these diagrams the parallel trend pattern of element frequency reveals the same origin and their evolution through the fractional crystallisation of primary magmas (Nicholson et al. 2004). Enrichment in LREE and LILE, as well as the depletion in HREE 
TAS (Le Bas et al, 1986)

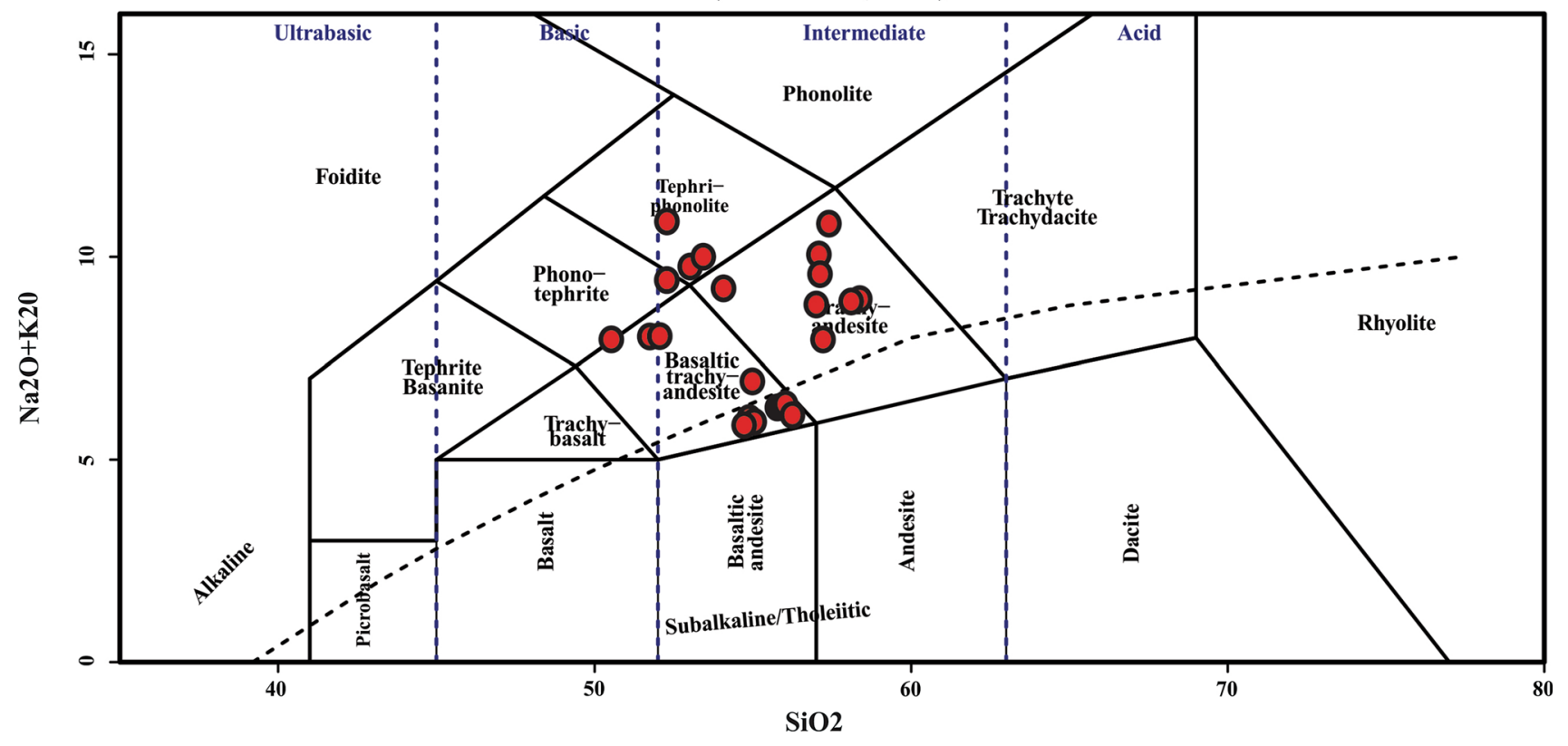

Figure 7. Position of samples in TAS diagram (Le Bas et al. 1986).

and HFSE, is considered as characteristics of calc-alkaline rocks in active continental margin volcanoes (Nagudi et al. 2003) and of subduction zones (Zanetti et al. 1999; Winter 2001; Wilson 2007; Gill 2010). Primary magma for the studied volcanic rocks might be derived from the subducting oceanic crust above the mantle wedge. Geochemical characteristics of this magma, such as HFSE and HREE, change as it ascends to the surface due to fractional crystallisation and assimilation with the crust components. $\mathrm{Nb}$ and $\mathrm{Ti}$ (Thompson 1982) have a negative anomaly in the spider diagram. Negative anomalies of HFSEs, such as $\mathrm{Nb}$ and $\mathrm{Ti}$, are the features of arc settings (Wilson 2007). It may also be due to the contamination and magma mixing with crustal material during the ascent and replacement in subduction zones (Wilson 2007). Some researchers have suggested that the depletion of melted mantle wedge is due to the presence of long-lasting phases containing these elements (such as rutile, pargasitit amphibole, sphene, apatite and ilmenite) in eclogitic rocks of the subducted oceanic crust or non-melted mantle wedges as these elements are very compatible in the aforementioned phases (Ayers 1998).

LILE/HFSE enrichment is a feature of subduction environments (Taylor and Martinez 2003). Such a high ratio in the rocks of arctic areas can be attributed to the introduction of LILE components of the subducted ocean crust into the mantle wedge above (Mohamed et al. 2000). This depletion of HFSE but not LILE is because of the influence of fluids or melts that result from the oceanic subducted slab into the sub-continental mantle in the arc zone (Winter 2001). The negative anomalies of $\mathrm{Nb}$ and $\mathrm{Ti}$, which led to the zigzag pattern in the variation trend of rare elements, are representative of subduction zones. As a matter of fact, in these regions, the released fluids from the subducted lithosphere (poor in $\mathrm{Nb}$ and rich in LILE) are increased in the mantle wedge. Based on Aldanmaz et al. (2006) the negative anomaly of $\mathrm{Nb}$ indicates an active continental margin and is the result of the contaminated and subducted crust materials. Titanium element in the subduction zone has a negative anomaly due to high oxygen fugacity and high melting temperatures of titanium-bearing minerals (Ionov and Hofman 1995).

\subsection{Tectonic setting}

The geochemical characteristics of the samples have been used to evaluate the tectonic setting of igneous rocks in the area. The Peshtasar basalts show ultra-potassic $\left(\mathrm{K}_{2} \mathrm{O} / \mathrm{Na}_{2} \mathrm{O}>3\right.$; Foley and Peccerillo 1992) and shoshonitic (Le Maitre 2002) characteristics. $\mathrm{K}_{2} \mathrm{O}$ varies between 2.15 and 5.71 . Such rocks are known to occur in the calc-alkaline, island arc type, subduction zone volcanisms (Morrison 1980; Muller and Groves 2016). The 

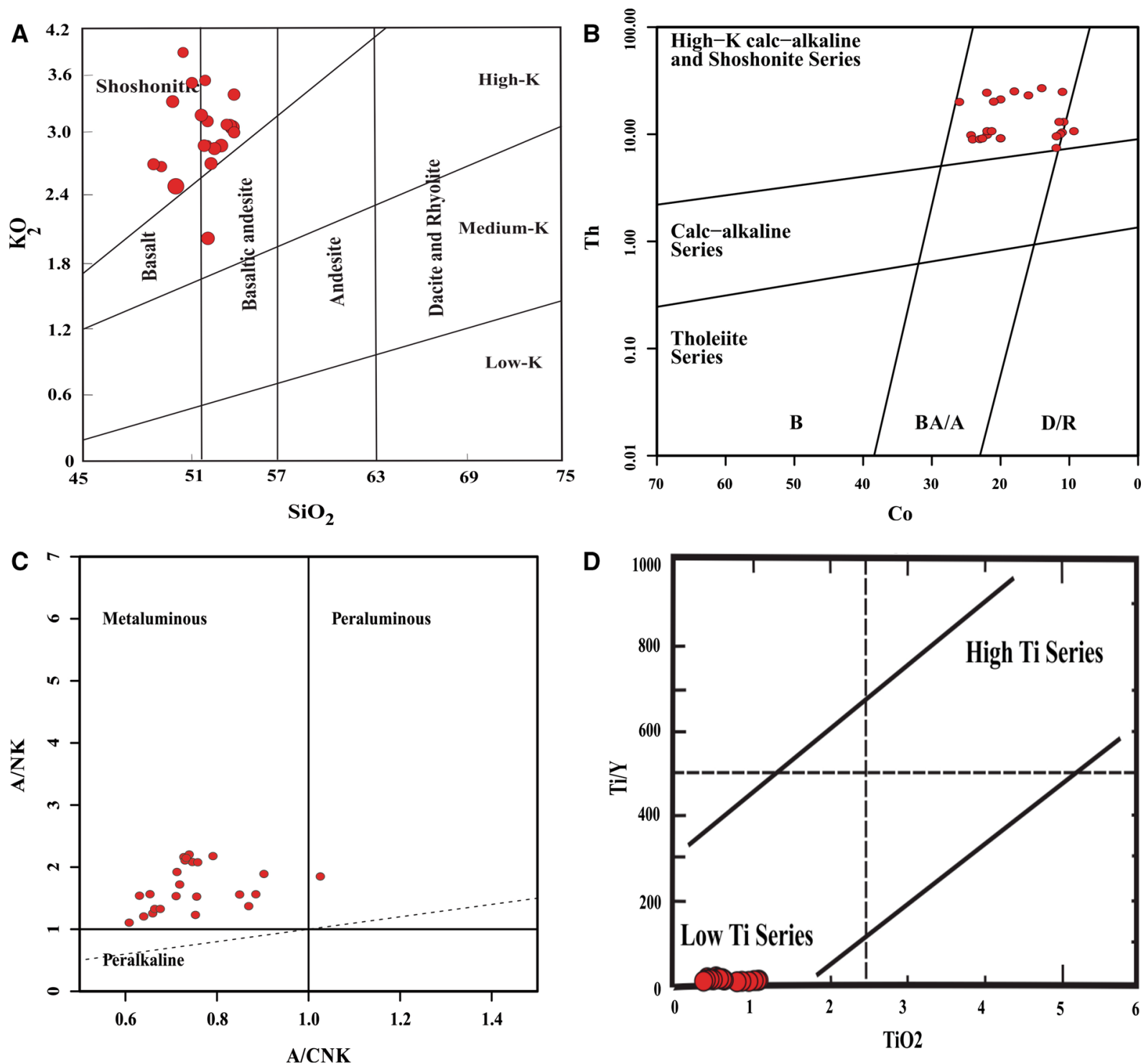

Figure 8. (A) $\mathrm{K}_{2} \mathrm{O}$ vs. $\mathrm{SiO}_{2}$ diagram (Le Maitre 2002). (B) Th vs. Co diagram (Hastie et al. 2007). (C) A/NK vs. A/CNK diagram (Shand 1943). The samples are located in the meta-aluminous field. (D) $\mathrm{Ti} / \mathrm{Y}$ vs. $\mathrm{TiO}_{2}$ diagram (Zhou et al. 2008). Samples are located in the Lowe titanium field.

Peshtasar basalts belong to island arc subductiontype environments. This fact is evident in the $\mathrm{Zr}$ vs. Y (figure 10A; Muller and Groves 1997), $\mathrm{Th} / \mathrm{Yb}$ vs. $\mathrm{Ta} / \mathrm{Yb}$ (figure 10B; Pearce 1983) and $\mathrm{DF}_{2}$ vs. $\mathrm{DF}_{1}$ (figure 10C; Agrawal et al. 2008) binary plots as well as $\mathrm{Nb} * 50-\mathrm{Ce} / \mathrm{P}_{2} \mathrm{O}_{5}-\mathrm{Zr} * 3$ (figure 10D; Muller and Groves 1997) ternary plot. Further support is received from trace element spider diagrams that indicate post-collision arc settings (figure 11; Muller and Groves 1997). Ba/La ratio in these basalts shows the features of igneous rocks in arc-related settings. This ratio is between 4 and 10 for NMORB and between 10 and 15 for EMORB and more intra-plate basalts, while it is greater than 15 for the volcanic rocks of convergent plate boundaries (Wood 1980). It is higher in volcanic arcs than tensile regions and back-arc basins. This ratio varies between 22.22 and 48.36 (average 33.57) for Peshtasar basalts like those of arc magmas. Another important geochemical proxy is $\mathrm{Ba} / \mathrm{Ta}$ ratio, which is higher than 450 in arc magmas (Macdonald et al. 2000). This ratio is between 493.83 and 1584.21 for the Peshtasar basalts. Thus, several lines of evidence indicate that the studied rocks represent the basalts of island-arc tectonic settings (average 919.10). The $\mathrm{TiO}_{2}$ content is less than $1.3 \mathrm{wt} \%$ (Macdonald et al. 2000). 

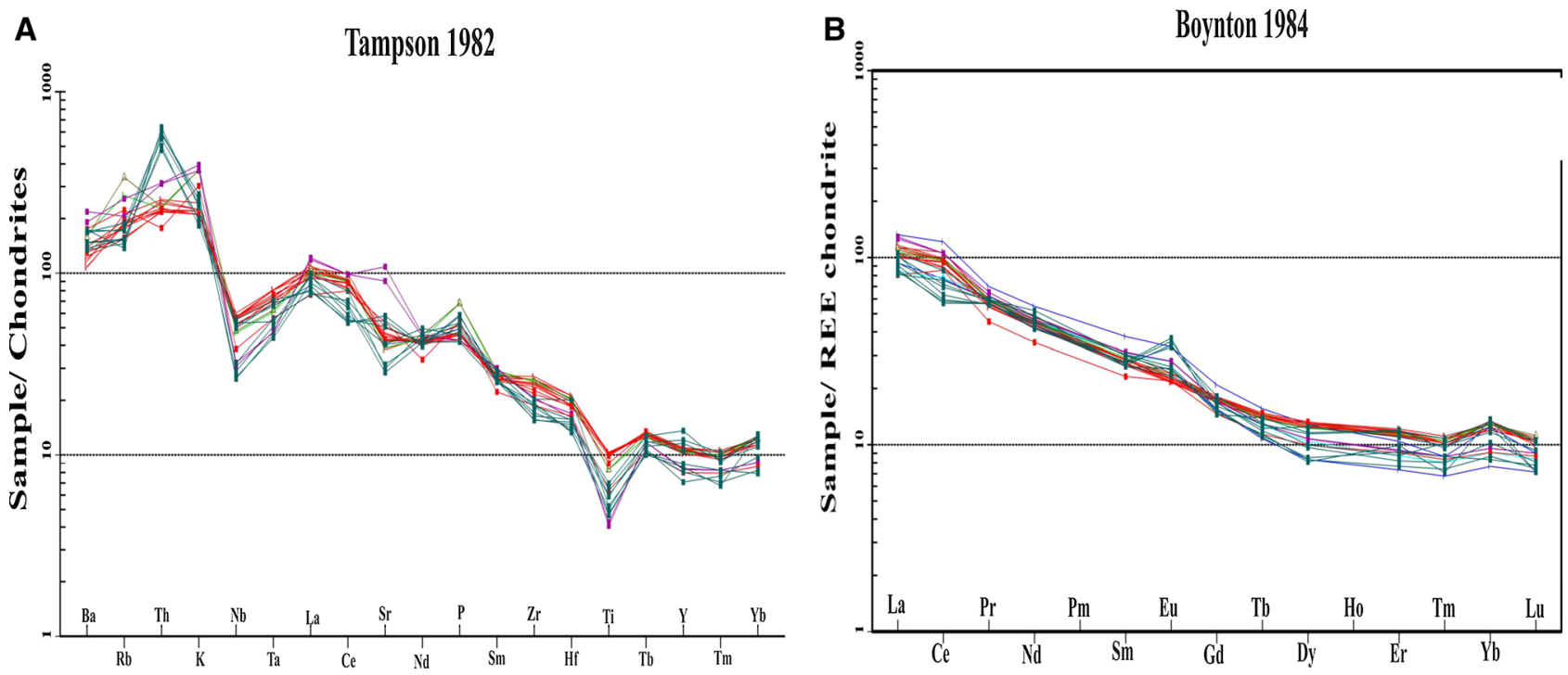

Figure 9. Spider diagrams of Moghan sedimentary basin samples: (A) normalised chondrite in basalt (Thompson 1982) and (B) normalised to rare earth element of chondrite in basalt (Boynton 1984).
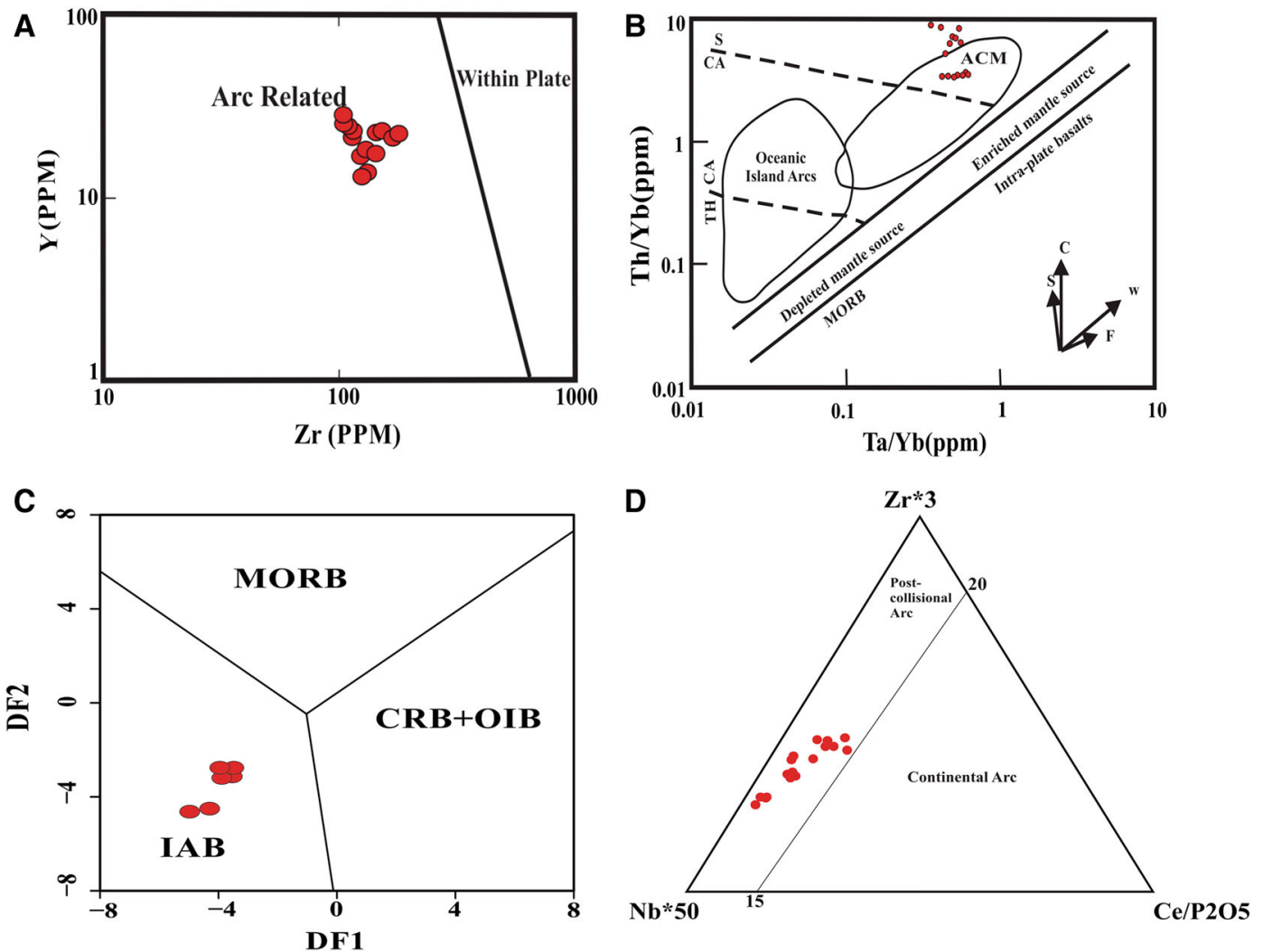

Figure 10. Tectonic setting discrimination diagrams of Moghan sedimentary basin Peshtasar basalts: (A) Y vs. Zr diagram (Muller and Groves 1997), basaltic rocks are located in volcanic arcs; (B) Ta/Yb vs. Th/Yb diagrams (Pearce 1983), basaltic rocks are located in active continental margin; (C) Agrawal et al. (2008) diagram, the samples are located within island arc; and (D) triangular diagram (Muller and Groves 1997), the samples are located in post-collision arc setting.

\subsection{Implications for crustal contamination}

Magma contamination with crustal materials increases the amount of $\mathrm{Rb}, \mathrm{Ba}$ and $\mathrm{K}$, although
$\mathrm{Nb}, \mathrm{Zr}$, Ti and Y remain intact (Reichow et al. 2005). Several geochemical diagrams have been routinely used to investigate crustal contamination. The $\mathrm{Rb} / \mathrm{Y}$ vs. $\mathrm{Nb} / \mathrm{Y}$ diagram 
(Edwards et al. 1991) shows that the Peshtasar basalts have a vertical trend indicating either fluid enrichment in the subduction zone or crustal contamination (figure 12A). The basalts found in the subduction zone usually show low values of $\mathrm{Nb} / \mathrm{Y}$, which is generally attributed to the depletion of HFS elements. In such regions, HFS elements (such as $\mathrm{Ti}, \mathrm{Nb}$ ) remain on the subducted plate due to their inability to dissolve. In contrast, LIL elements (such as $\mathrm{Ba}, \mathrm{Rb}, \mathrm{K}$ ) that are able to dissolve, are easily transmitted to the upper part of the mantle at high temperatures and pressures (Pearce 1983). The $\mathrm{Nb} / \mathrm{U}$ ratio is less than 47 and displays the contribution of the crustal material in magma generation (Hofmann et al. 1986). The low

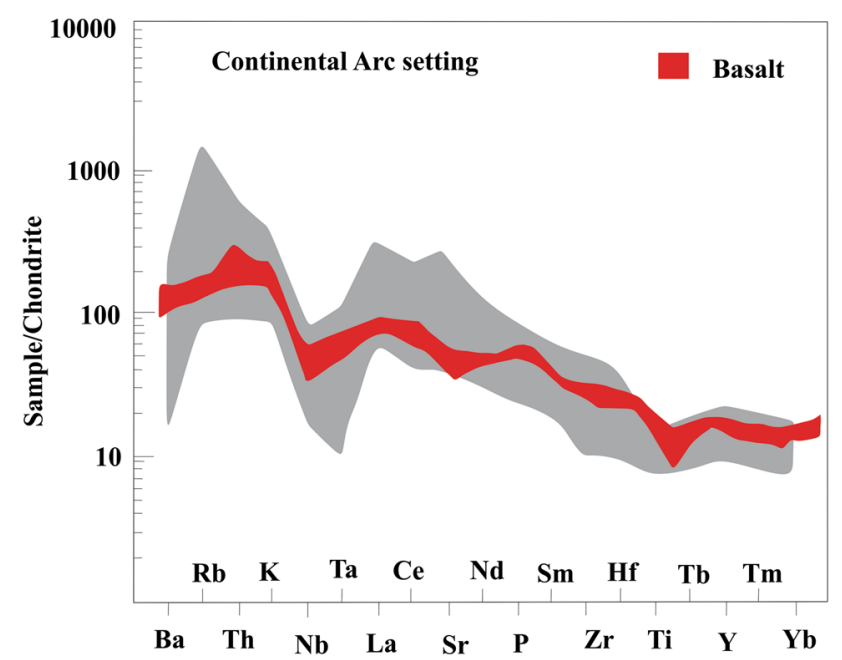

Figure 11. Multivariate diagrams normalised to chondrite (Muller and Groves 1997).

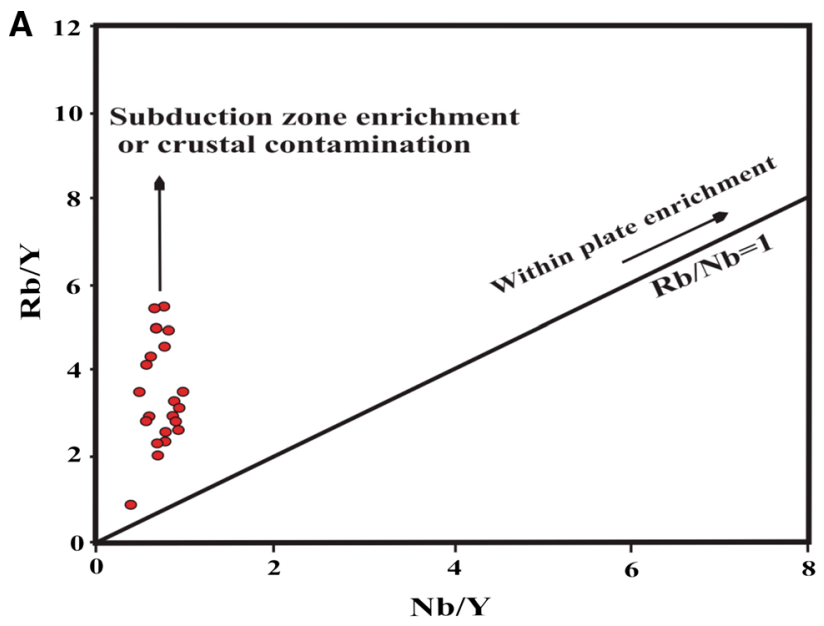

$\mathrm{Nb} / \mathrm{U}$ ratio (less than 47 ) in the studied basalts indicates the involvement of crustal material in the evolution of Peshtasar basalts. The La/Sm ratio is used to model crustal contamination (DePaolo 1981) in which various values of $r$ and diagonal curves are shown. In fact, the value of ' $r$ ' represents assimilation rate in comparison with fractional crystallisation rate. The closer the composition of rocks is to the composition of the crust, the higher the $r$ value will be (Keskin et al. 1998). Except for three samples with the $r$ values less than 0.03, for Peshtasar basalts it is in the range of $0.03-0.15$. This range shows fractionation process as the dominant one with very little crustal contamination (figure $12 \mathrm{~B}$ ). A low $\mathrm{Nb} / \mathrm{Th}$ ratio is a continental crust feature (Rudnick and Fountain 1995). This ratio is low in the studied samples varying from 0.37 to 2.16 in basalts. In $\mathrm{Nb} / \mathrm{Th} v s$. Th diagram, which is used to determine crustal contamination, basalts are located in the range of upper crustal composition (Taylor and McLennan 1981) (figure 13A). Rb/La vs. Th diagram confirmed crustal contamination. Basaltic samples are located near the upper crustal composition in this chart (Taylor and McLennan 1981) (figure 13B). All the samples have a trend along AFC and FC (assimilation-fractional crystallisation and fractional crystallisation) in the $\mathrm{K}_{2} \mathrm{O} / \mathrm{Na}_{2} \mathrm{O}$ vs. $\mathrm{Rb} / \mathrm{Zr}$ diagram (Esperança et al. 1992) (figure 13C). Basalts show crustal contamination and fractional crystallisation trends in the $\mathrm{Th} / \mathrm{Yb}$ vs. $\mathrm{Ta} / \mathrm{Yb}$ diagram (Pearce 1983) (figure 10B). In the $\mathrm{Th} / \mathrm{Nb}$ vs. Ba/Th diagram (Orozco-Esquivel et al. 2007), which is used to investigate the upper sedimentary

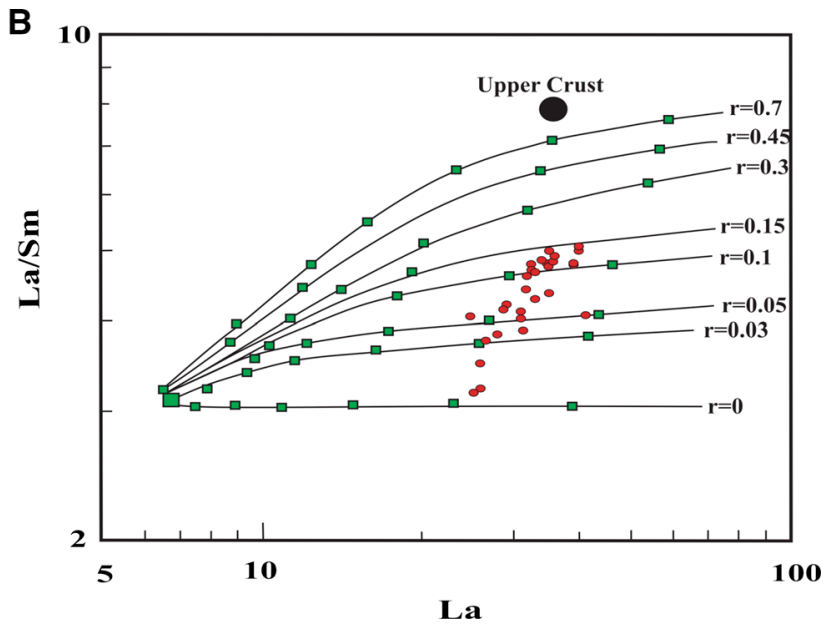

Figure 12. Crustal contamination diagrams of Moghan sedimentary basin Peshtasar basalts: (A) Rb/Y vs. Nb/Y diagram (Edwards et al. 1991), enrichment of the samples by fluids in subduction zone or crustal contamination and (B) La/Sm vs. La diagram (DePaolo 1981). 

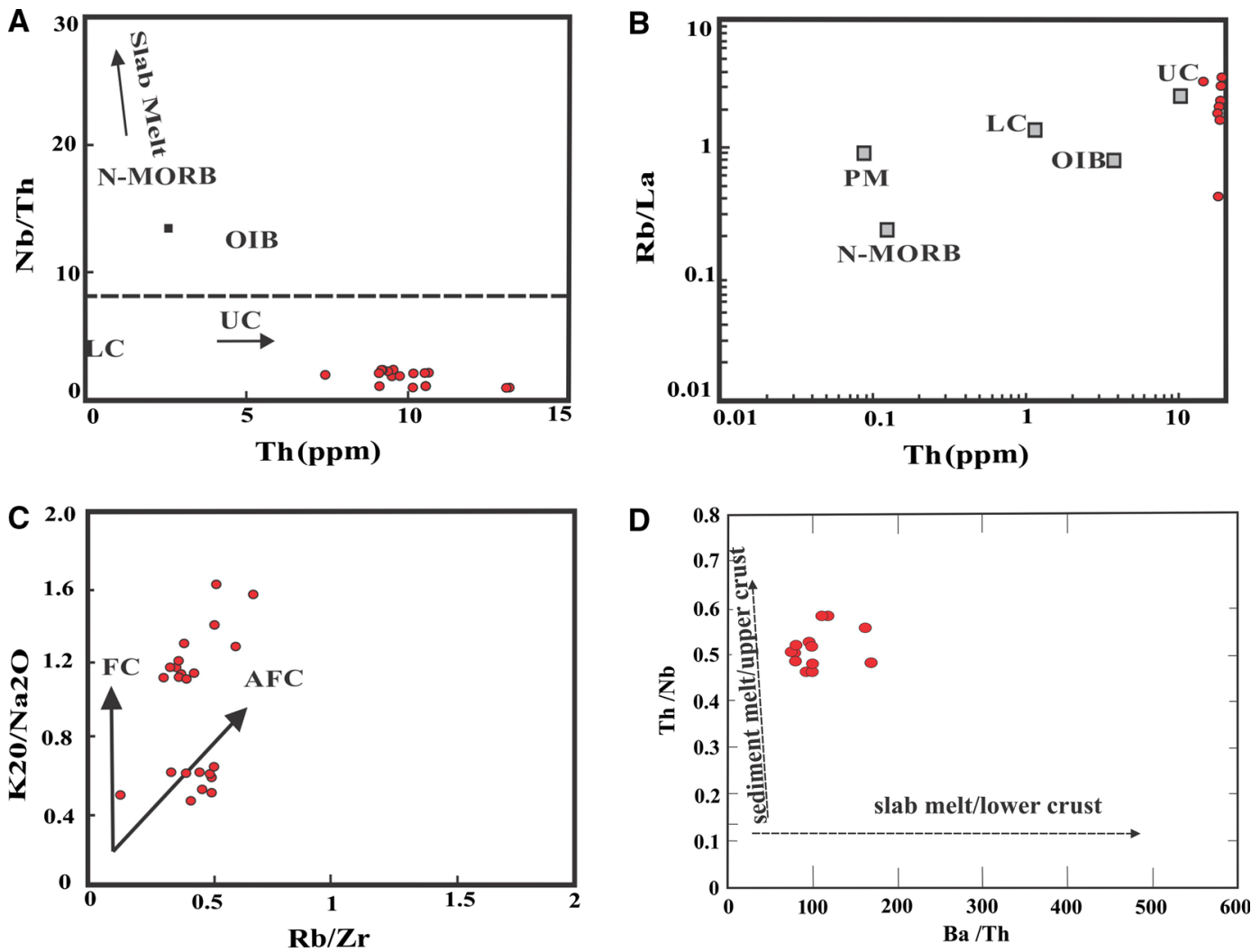

Figure 13. Crustal contamination diagrams of Moghan sedimentary basin Peshtasar basalts: (A) Nb/Th vs. Th diagram (Taylor and McLennan 1981), (B) Rb/La vs. Th diagram (Taylor and McLennan 1981), (C) $\mathrm{K}_{2} \mathrm{O} / \mathrm{Na}_{2} \mathrm{O}$ vs. Rb/Zr diagram (Esperança et al. 1992). Samples have a trend along AFC and FC. (D) Th/Nb vs. Ba/Th diagram (Orozco-Esquivel et al. 2007).

of the subducted plate and lower crustal melting, low $\mathrm{Ba} / \mathrm{Th}$ and $\mathrm{Th} / \mathrm{Nb}$ values indicate slight contributions of subduction zone materials (solutions and melt materials) and the effect of crustal contamination on the rocks' formation. High values of $\mathrm{Th} / \mathrm{Nb}$ and low values of $\mathrm{Ba} / \mathrm{Th}$ indicate that upper crust materials contributed dominantly in the formation of the rocks. Peshtasar basalts of the Moghan basin show high values of $\mathrm{Th} / \mathrm{Nb}$ and low values of $\mathrm{Ba} / \mathrm{Th}$. According to geochemical diagrams, melting of the subducted plate, upper crust composition and the extent of their participation play important roles in the formation of these rocks (figure 13D).

\subsection{The origin of igneous rocks in Moghan basin}

The La/Sm vs. La diagram (Aldanmaz et al. 2000) has been used to identify the mineralogical composition of the source and the degree of partial melting in basalts. Peshtasar basalts are consistent with the melting curve of garnet lherzolite and show $1-5 \%$ of melting (figure 14A). One of the characteristics of the melting process in the subducted plate (slab) is $(\mathrm{La} / \mathrm{Yb})_{N}>12$ (Defant and Drummond 1990). The mean value of this ratio for basalts is 8.19. It is lower than this value which indicates the derivation of basalts from mantle magmas. According to the $\mathrm{Y}$ vs. Zr diagram (Abu-Hamatteh 2005) the basalts are located within the enriched mantle range (figure 14B). Based on the $\mathrm{Ce} / \mathrm{Yb}$ vs. Ce diagram (Ellam 1992), the igneous rocks derived from a depth of $100-110 \mathrm{~km}$ indicating a partial melting within the garnet-lherzolite field (figure 14C). In the $\mathrm{Nb} / \mathrm{La}$ vs. La/Yb diagram (Fitton et al. 1991; Chen and Arculus 1995) the $\mathrm{Nb} / \mathrm{La}$ ratio is greater than 1 for the asthenospheric mantle and smaller than 0.5 for the lithospheric mantle. Basaltic samples belong to the lithospheric mantle area. Some of them, however, indicate a deeper source (figure $14 \mathrm{D}$ ). The average $\mathrm{Nb} / \mathrm{La}$ is 0.48 for basalts. To determine the role of the participant components in magmatic arcs, the $\mathrm{Th} / \mathrm{Nb}$ vs. $\mathrm{Ba} / \mathrm{Th}$ diagram (Orozco-Esquivel et al. 2007) is used. According to this diagram the melting of the upper sediments in the subducted plate, the metasomatism of the upper crust and mantle origin enrichment play important roles (figure 13D). Rare element 


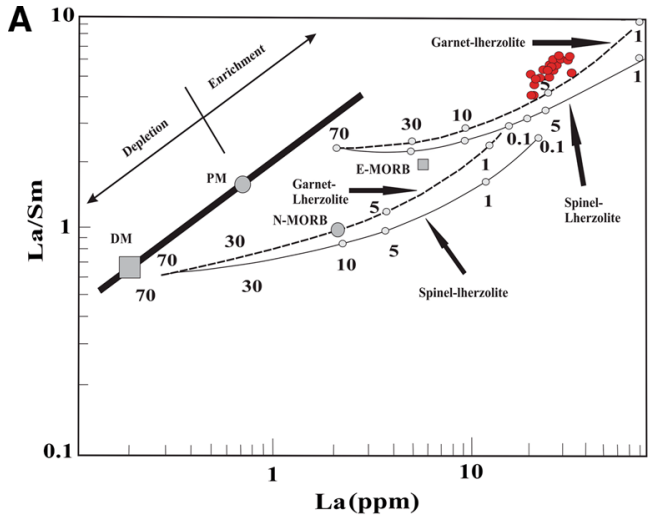

C

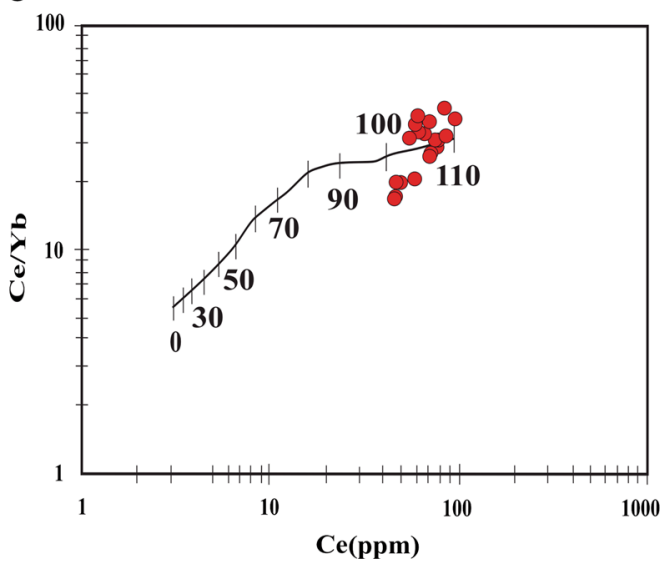

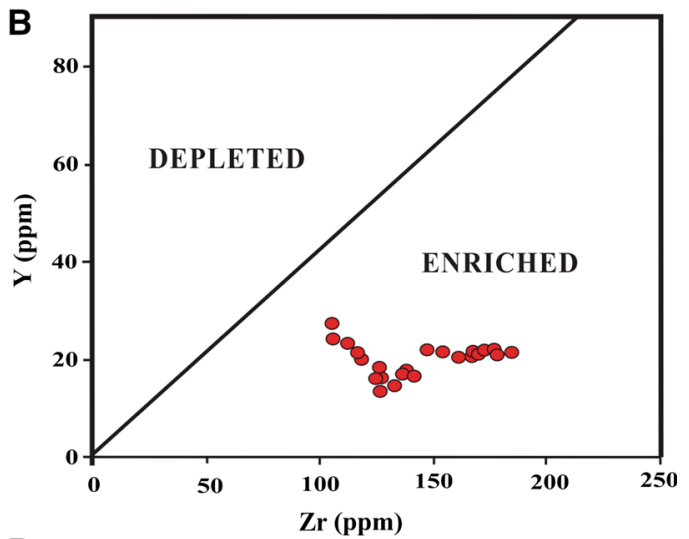

D

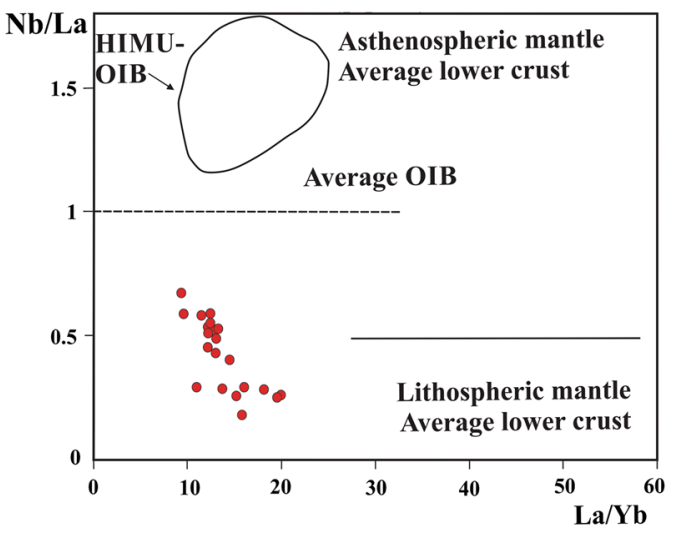

Figure 14. Mantle origin characteristic diagrams of Moghan sedimentary basin igneous rocks: (A) La/Sm vs. La diagram (Aldanmaz et al. 2000), correlation samples with melting curve of garnet lherzolite; (B) Y vs. Zr diagram (Abu-Hamatteh 2005), samples are located within enriched mantle range; (C) Ce/Yb vs. Ce diagram (Ellam 1992), indicates depth of the melting location of igneous rocks origin from 100 to $110 \mathrm{~km}$ of studied samples; (D) Nb/La vs. La/Yb diagram (Fitton et al. 1991; Chen and Arculus 1995), location of samples in lithospheric mantle field.

concentrations and ratios are used to identify mantle sources (HIMU, EM1, EM2). The K/La ratio is greater than 260 in EM basalts and less than 260 in the HIMU basalts; the concentration of $\mathrm{Rb}$ is greater than $30 \mathrm{ppm}$ in EM basalts and less than $30 \mathrm{ppm}$ in HIMU basalts (Willbold and Stracke 2006). The average K/La ratio and $\mathrm{Rb}$ concentration are 937.33 and $64.28 \mathrm{ppm}$, respectively, in these basalts representing the EM domain. Besides, the $\mathrm{Nb} / \mathrm{Rb}$ ratio is different in EM from HIMU basalts. In fact, this ratio is less than 1.5 in EM1 and EM2 basalts, whereas it is greater than 2.5 in HIMU basalts (Willbold and Stracke 2006). The average $\mathrm{Nb} / \mathrm{Rb}$ is 0.26 in studied basalts. $\mathrm{K}$ depletion is the feature of HIMU basalts that makes them different from EM1 and EM2 types (Chauvel et al. 1992). Potassium enrichment is obvious in normalised diagrams. Hence, the geochemistry of rare elements indicates the mantle origin of the EM type for the studied rocks.

Considering the importance of the lithology and the origin of the studied samples, ${ }^{87} \mathrm{Sr} /{ }^{86} \mathrm{Sr}$ and ${ }^{143} \mathrm{Nd} /{ }^{144} \mathrm{Nd}$ analyses were performed on five samples to determine the primary magma origin at the University of Portugal, Aveiro. The results of the analyses are presented in table 2. The ${ }^{87} \mathrm{Sr} /{ }^{86} \mathrm{Sr}$ isotopes vary in the range of 0.704759 0.705387 . The maximum value is observed in the Germi and Tazehkand samples, while the minimum value belongs to the Shahyourdi samples. $\mathrm{Nd}$ isotopic ratio $\left({ }^{143} \mathrm{Nd} /{ }^{144} \mathrm{Nd}\right)$ varies from 0.512650 to 0.512782 , for which the maximum and minimum values are identified in Shahyourdi and Tazehkand basalts, respectively. $\varepsilon \mathrm{Sr}$ and $\varepsilon \mathrm{Nd}$ have been calculated based on the relative age of the samples ( 35 million years). Positive $\varepsilon \mathrm{Sr}$ and $\varepsilon \mathrm{Nd}$ values vary between 2.90 and 10.76 and 0.54 and 3.09, respectively. Positive $\varepsilon N d$ values indicate that the igneous rocks derived from a parental magma of mantle origin. These rocks are the results of old partial melting events that have suffered depletion. The measured ${ }^{143} \mathrm{Nd} /{ }^{144} \mathrm{Nd}$ values are higher than that of the present chondritic uniform reservoir $(0.512638)$. Considering the small variation in $\varepsilon \mathrm{Nd}$, 

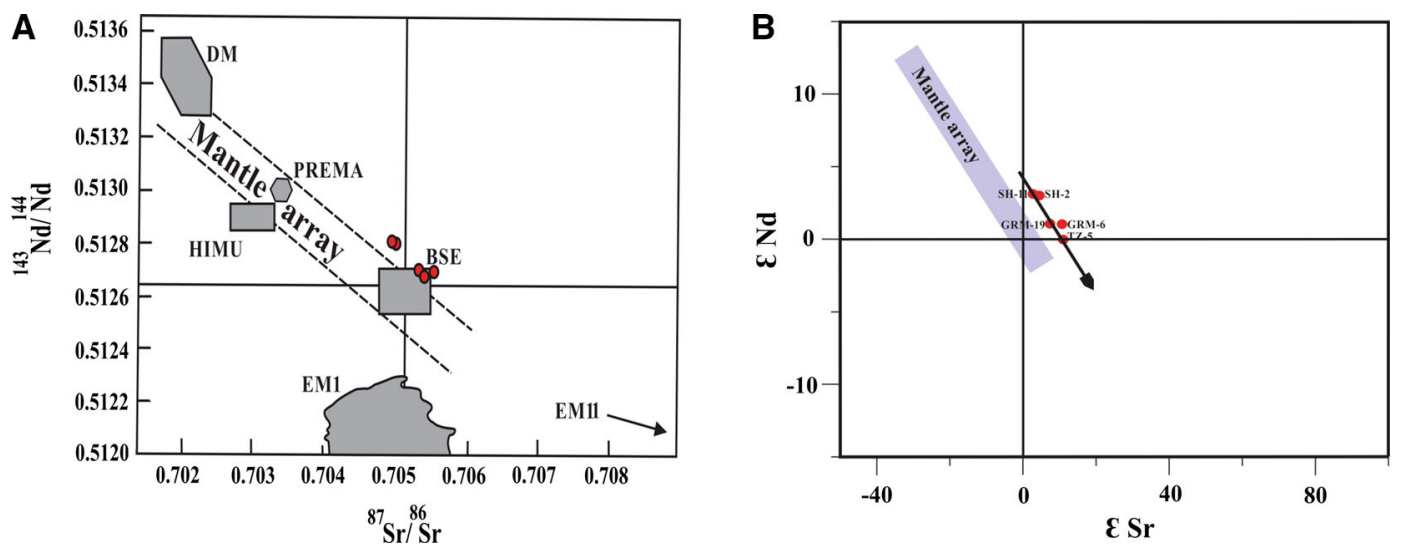

Figure 15. Isotope correlation diagrams of Moghan sedimentary basin Peshtasar basalts: $(\mathbf{A}){ }^{143} \mathrm{Nd} /{ }^{144} \mathrm{Nd} v s .{ }^{87} \mathrm{Sr} /{ }^{86} \mathrm{Sr}$ diagram (Zindler and Hart 1986), location of samples in lithospheric mantle array; (B) $\varepsilon$ Nd vs. $\varepsilon$ Sr diagram, samples are located on the right side of mantle array (Arjmandzadeh and Santos 2014). Upper continental crust (Taylor and McLennan 1985), lower continental crust (Rudnick and Fountain 1995).

the depletion process was found to be relatively weak as it has been formed during a partial melting degree of less than $5 \%$. In the $\mathrm{Sr}-\mathrm{Nd}$ correlation diagram, the samples are plotted within or near the bulk silicate Earth to the right of the mantle array (figure 15A). In this diagram the samples have a trend towards Area 4. As a matter of fact, the difference in $\mathrm{Sr}$ and $\mathrm{Nd}$ variations is related to different mantle origins. Based on the ${ }^{87} \mathrm{Sr} /{ }^{86} \mathrm{Sr}$ ratio, Shahyourdi samples have enriched mantle origin (EM1) and indicate pelagic sediments as their source, while Germi and Tazehkand samples have enriched mantle origin (EM11) and indicate terrigenous sediments in their source. The samples show the same features in $\varepsilon N d$ vs. $\varepsilon$ Sr diagram (figure 15B). Considering the tectonic setting of Peshtasar basalts that is related to a post-collision arc and the sea water enrichment in $\mathrm{Sr}$ and lack of $\mathrm{Nd}$, the fluids that are released from the subducted oceanic crust into the mantle wedge over the subduction zone increased the strontium isotope of metasomatised mantle. Fluids released from the subducted oceanic crust may result in higher $\mathrm{Rb} / \mathrm{Sr}$ ratios (Faure 1986).

\section{Conclusion}

In terms of the magmatic series, the Peshtasar basalts indicate high potassium calc-alkaline to shoshonitic characteristics. Based on the geochemical diagrams and rare elements these rocks are formed in an active continental margin and a post-collision arc system. Moreover, chondritenormalised REE patterns confirm that these basalts are formed in a post-collisional setting. The patterns of trace elements and REE variations indicate enrichments in LILE and LREE and depletion in HFSE and HREE in these rocks. Binary and ternary variation diagrams, geochemical parameters and element ratios indicate evolved magmas. The fractional crystallisation was a dominant mechanism in the evolution of the basaltic magma. The geochemical data indicate that the Peshtasar basalts were formed in a post-collision island-arc tectonic setting. Moreover, $1-5 \%$ partial melting of the enriched garnet-lherzolite origin is attributed to the genesis of the studied basalts. Although all these basalts originated from a lithospheric mantle source, they are formed in different depths. Based on the $\mathrm{Ce} / \mathrm{Yb}$ vs. $\mathrm{Ce}$ diagram, basalts derived from a depth of 100 $110 \mathrm{~km}$, which is representative of a partial melting within the garnet-lherzolite zone. The results of the isotopic analyses of five samples of Peshtasar basalts using ${ }^{87} \mathrm{Sr} /{ }^{86} \mathrm{Sr}$ and ${ }^{143} \mathrm{Nd} /{ }^{144} \mathrm{Nd}$ ratios and the calculated results of $\varepsilon \mathrm{Sr}$ and $\varepsilon \mathrm{Nd}$ suggest that these rocks have lithospheric mantle sources. Based on the ${ }^{87} \mathrm{Sr} /{ }^{86} \mathrm{Sr}$ ratio Shahyourdi samples have an enriched mantle origin (EM1) and show pelagic sediments in their source, while Germi and Tazehkand samples have an enriched mantle origin (EM11) and indicate terrigenous sediments in their source. These geochemical characteristics indicate different mantle origins of basalts in the central, western and eastern Moghan basin. Based on geochemical diagrams, the role of the upper crust in the crustal contamination of basalt-forming magma is more important. The palaeontological evidence in the upper and lower sediments of 
Peshtasar basaltic lava confirms the Eocene age for this complex (Fotouhi 1973). These lavas are derived from an enriched lithospheric mantle source in a post-collisional magmatic arc setting (Moayyed 2001, 2002), which has undergone crustal contamination, fractional crystallisation and crystalline partition. This has led to the further evolution of a primary basaltic magma.

\section{Acknowledgements}

This work was conducted as a part of the $\mathrm{PhD}$ thesis of A Amraee. We also acknowledge the editor and the anonymous reviewers for their constructive comments which helped to improve this paper.

\section{References}

Abu-Hamatteh Z 2005 Geochemistry and petrogenesis of mafic magmatic rocks of the Jharol Belt, India: Geodynamic implication; J. Asian Earth Sci. 25(4) 557-581.

Aghanabati A 2004 Geology of Iran; Geological Survey of Iran, Tehran, pp. 578-582, Farsi (in Persian).

Agrawal S, Guevara M and Verma S P 2008 Tectonic discrimination of basic and ultrabasic volcanic rocks through log-transformed ratios of immobile trace elements; Int. Geol. Rev. 50(12) 1057-1079.

Aldanmaz E, Pearce J A, Thirlwall M F and Mitchell J G 2000 Petrogenetic evolution of late Cenozoic, postcollision volcanism in western Anatolia, Turkey; J. Volcanol. Geotherm. Res. 102(1) 67-95.

Aldanmaz E, Köprübaşı N, Gürer Ö F, Kaymakçı N and Gourgaud A 2006 Geochemical constraints on the Cenozoic, OIB-type alkaline volcanic rocks of NW Turkey: Implications for mantle sources and melting processes; Lithos 86(1) 50-76.

Arjmandzadeh R and Santos J F 2014 Sr-Nd isotope geochemistry and tectonomagmatic setting of the Dehsalm $\mathrm{Cu}-\mathrm{Mo}$ porphyry mineralizing intrusives from Lut Block, eastern Iran; Int. J. Earth Sci. (Geol Rundsch) 103 123140.

Ayers J 1998 Trace element modeling of aqueous fluidperidotite interaction in the mantle wedge of subduction zones; Contrib. Mineral. Petrol. 132(4) 390-404.

Badiozamani K H 1967 Geological study of south east of Moghan in terms of lithology, stratigraphy and oil facilities; Master's Dissertation Thesis, Faculty of Science, University of Tehran, Tehran, Iran (in Persian).

Barrier E and Vrielynck B 2008 Paleotectonic maps of the Middle East; Middle East Basins Evolution Programme, CGMW, Atlas, Maps, pp. 1-14.

Basaltic Volcanism Study Project 1981 Basaltic volcanism on the terrestrial planets; Pergamon Press Inc., New York, USA.

Boynton W 1984 Cosmochemistry of the rare earth elements: Meteorite studies; In: Developments in Geochemistry, Elsevier, 2 63-114.
Brunet M F, Granath J W and Wilmsen M 2009 South Caspian to central Iran basins: Introduction; Geol. Soc. Lond. Spec. Publ. 312(1) 1-6.

Chauvel C, Hofmann A W and Vidal P 1992 HIMU-EM: The French Polynesian connection; Earth Planet. Sci. Lett. 110(1-4) 99-119.

Chen W and Arculus R J 1995 Geochemical and isotopic characteristics of lower crustal xenoliths, San Francisco Volcanic Field, Arizona, USA; Lithos 36(3-4) 203-225.

Defant M J and Drummond M S 1990 Derivation of some modern arc magmas by melting of young subducted lithosphere; Nature 347(6294) 662-665.

DePaolo D J 1981 Trace element and isotopic effects of combined wallrock assimilation and fractional crystallization; Earth Planet. Sci. Lett. 53(2) 189-202.

Downes H, Seghedi I, Szakacs A, Dobosi G, James D E and Vaselli O Z et al. 1995 Petrology and geochemistry of late Tertiary/Quaternary mafic alkaline volcanism in Romania; Lithos 35(1-2) 65-81.

Edwards C, Menzies M and Thirlwall M 1991 Evidence from Muriah, Indonesia, for the interplay of supra-subduction zone and intraplate processes in the genesis of potassic alkaline magmas; J. Petrol. 32(3) 555-592.

Ellam R 1992 Lithospheric thickness as a control on basalt geochemistry; Geology 20(2) 153-156.

Esperança S, Crisci G M, De Rosa R and Mazzuoli R 1992 The role of the crust in the magmatic evolution of the island of Lipari (Aeolian Islands, Italy); Contrib. Mineral. Petrol. 112(4) 450-462.

Faure G 1986 Principles of Isotope Geology; 2nd edn, John Wiley \& Sons, New York.

Fitton J G, James D and Leeman W P 1991 Basic magmatism associated with late Cenozoic extension in the western United States: Compositional variations in space and time; J. Geophys. Res. Solid Earth 96(B8) 13,69313,711 .

Foley S and Peccerillo A 1992 Potassic and ultrapotassic magmas and their origin; Lithos 28 181-185.

Fotouhi M 1973 A comprehensive review of geology and oil possibilities in Moghan area; Geological Report, National Iranian Oil Company, 348p.

Gaetani G A 2004 The influence of melt structure on trace element partitioning near the peridotite solidus; Contrib. Mineral. Petrol. 147(5) 511-527.

Gill R 2010 Igneous Rocks and Processes: A Practical Guide; John Wiley \& Sons, New York.

Golonka J 2004 Plate tectonic evolution of the southern margin of Eurasia in the Mesozoic and Cenozoic; Tectonophys. 381(1) 235-273.

Gourgaud A and Vincent P 2004 Petrology of two continental alkaline intraplate series at Emi Koussi volcano, Tibesti, Chad; J. Volcanol. Geotherm. Res. 129(4) 261290.

Gust D A and Perfit M R 1987 Phase relations of a high$\mathrm{Mg}$ basalt from the Aleutian island arc: Implications for primary island arc basalts and high-Al basalts; Contrib. Mineral. Petrol. 97(1) 7-18.

Hastie A R, Kerr A C, Pearce J A and Mitchell S F 2007 Classification of altered volcanic island arc rocks using immobile trace elements: Development of the Th-Co discrimination diagram; J. Petrol. 48(12) 2341-2357. 
Hofmann A W, Jochum K P, Seufert M and White W M $1986 \mathrm{Nb}$ and $\mathrm{Pb}$ in oceanic basalts: New constraints on mantle evolution; Earth Planet. Sci. Lett. 79(1-2) 3345.

IFP 1961 Geological Report Number 235, NIOC, pp. 10-20. Ionov D A and Hofman A W 1995 Nb-Ta-rich mantle amphiboles and micas: Implication for subduction-related metasomatic trace element fractionations; Earth Planet. Sci. Lett. 131 341-356.

Irvine T and Baragar W 1971 A guide to the chemical classification of the common volcanic rocks; Can. J. Earth Sci. 8(5) 523-548.

Jenner G A, Cawood P A, Rautenschlein M and White W M 1987 Composition of back-arc basin volcanics, Valu Fa Ridge, Lau Basin: Evidence for a slab-derived component in their mantle source; J. Volcanol. Geotherm. Res. 32(1-3) 209-222.

Keskin M, Pearce J A and Mitchell J G 1998 Volcanostratigraphy and geochemistry of collision-related volcanism on the Erzurum-Kars Plateau, northeastern Turkey; J. Volcanol. Geotherm. Res. 85(1) 355-404.

Kim J and Cho M 2003 Low-pressure metamorphism and leucogranite magmatism, northeastern Yeongnam Massif, Korea: Implication for Paleoproterozoic crustal evolution; Precamb. Res. 122(1-4) 235-251.

Kretz R 1983 Symbols for rock-forming minerals; Am. Mineral. 68 277-279.

Le Bas M J, Le Maitre R W, Streckeisen A and Zanettin B 1986 A chemical classification of volcanic rocks based on the total alkali-silica diagram; J. Petrol. 27 745750

Le Maitre R W (ed.) 2002 Igneous Rocks: A Classification and Glossary of Terms; 2nd edn, Cambridge University Press, Cambridge, 141p.

Le Maitre R W, Bateman P, Dudek A, Keller J, Lameyre Le Bas M J, Sabine P A, Schmid R, Sorensen H, Streckeisen A, Woolley A R and Zanettin B 1989 A Classification of Igneous Rocks and Glossary of Terms; Blackwell, Oxford.

Liu X and Liu W 2014 Source characteristics and tectonic setting of the Early and Middle Devonian volcanic rocks in the North Junggar, Northwest China: Insights from Nd-Sr isotopes and geochemistry; Lithos 184 27-41.

Macdonald R, Hawkesworth C J and Heath E 2000 The Lesser Antilles volcanic chain: A study in arc magmatism; Earth Sci. Rev. 49(1) 1-76.

Moayyed M 2001 Petrological investigations of VolcanoPlotonic Tertiary Rocks of West Alborz-Azerbaijan with a special view on Hashtjin Area; Faculty of Science, Tehran, Iran, Shahid Beheshti, 328p (in Persian).

Moayyed M 2002 New attitude on evolution of Neo-Tethys and its relationship with tertiary Magmatism in UrmiaDokhtar and West Alborz-Azerbayjan; In: Proceedings of the sixth Iranian Geological Society conference, Shahid Bahonar University of Kerman, Kerman, Iran (in Persian).

Mohamed F H, Moghazi A M and Hassanen M A 2000 Geochemistry, petrogenesis and tectonic setting of late Neoproterozoic Dokhan-type volcanic rocks in the Fatira area, eastern Egypt; Int. J. Earth Sci. 88(4) 764-777.

Morrison G 1980 Characteristics and tectonic settings of shoshonite rock association; Lithos 13 97-108.
Muller D and Groves D 1997 Potassic Igneous Rocks and Associated Gold-Copper Mineralization; 2nd edn, Springer, Berlin, Heidberg, New York.

Muller D and Groves D I 2016 Potassic Igneous Rocks and Associated Gold-Copper Mineralization; 4th edn, Mineral Resource Reviews, Springer, Heidelberg, 311p.

Nabavi M 1976 An introduction to the geology of Iran; Geological Survey of Iran, Farsi (in Persian).

Nagudi B, Koeberl C and Kurat G 2003 Petrography and geochemistry of the Singo granite, Uganda, and implications for its origin; J. Afr. Earth Sci. 36(1) 7387.

Nicholson K N, Black P M, Hoskin P W O and Smith I E M 2004 Silicic volcanism and back-arc extension related to migration of the Late Cainozoic Australian-Pacific plate boundary; J. Volcanol. Geotherm. Res. 131(3) 295306.

Orozco-Esquivel T, Petrone C M, Ferrari L, Tagami T and Manetti P 2007 Geochemical and isotopic variability in lavas from the eastern Trans-Mexican Volcanic Belt: Slab detachment in a subduction zone with varying dip; Lithos 93(1) 149-174.

Pearce J 1983 The role of the subcontinental lithosphere in magma genesis at active destructive plate margins; Cont. Basalts Mantle Xenoliths 230-249.

Pearce J A and Norry M J 1979 Petrogenetic implications of $\mathrm{Ti}, \mathrm{Zr}, \mathrm{Y}$, and $\mathrm{Nb}$ variations in volcanic rocks; Contrib. Mineral. Petrol. 69(1) 33-47.

Reichow M K, Saunders A D, White R V, Al'Mukhamedov A I and Medvedev A Y 2005 Geochemistry and petrogenesis of basalts from the West Siberian Basin: An extension of the Permo-Triassic Siberian Traps, Russia; Lithos 79(3) 425-452.

Rudnick R L and Fountain D M 1995 Nature and composition of the continental crust: A lower crustal perspective; Rev. Geophys. 33(3) 267-309.

Shand S J 1943 Eruptive Rocks: Their Genesis, Composition, Classification, and their Relation to Ore Deposits with a Chapter on Meteorites; John Wiley \& Sons, New York.

Taylor B and Martinez F 2003 Back-arc basin basalt systematics; Earth Planet. Sci. Lett. 210(3) 481-497.

Taylor S R and McLennan S M 1981 The composition and evolution of the continental crust: Rare earth element evidence from sedimentary rocks; Phil. Trans. Roy. Soc. Lond. A, Math. Phys. Sci. 381-399.

Taylor S R and McLennan S M 1985 The Continental Crust: Its Composition and Evolution; Blackwell Scientific Publication, Carlton, 312p.

Thompson R 1982 Magmatism of the British Tertiary volcanic province; Scot. J. Geol. 18(1) 49-107.

Willbold M and Stracke A 2006 Trace element composition of mantle end-members: Implications for recycling of oceanic and upper and lower continental crust; Geochem. Geophys. Geosys. 7(4).

Wilson M 1989 Petrogenesis; Igneous Unwin Hyman, London.

Wilson M 2007 Igneous Petrogenesis a Global Tectonic Approach; Springer, Berlin.

Winter J 2001 An Introduction to Igneous and Metamorphic Petrology; Prentice Hall, Upper Saddle River, NJ, $697 \mathrm{p}$. 
Wood D A 1980 The application of a ThHfTa diagram to problems of tectonomagmatic classification and to establishing the nature of crustal contamination of basaltic lavas of the British Tertiary Volcanic Province; Earth Planet. Sci. Lett. 50(1) 11-30.

Yoder Jr H S and Tilley C E 1962 Origin of basalt magmas: An experimental study of natural and synthetic rock systems; J. Petrol. 3(3) 342-532.

Zanetti A, Mazzucchelli M, Rivalenti G and Vannucci R 1999 The Finero phlogopite-peridotite massif: An example of subduction-related metasomatism; Contrib. Mineral. Petrol. 134(2-3) 107-122.

Corresponding editor: RAJNEEsh BHUtAnI
Zhou M F, Arndt N T, Malpas J, Wang C Y and Kennedy A K 2008 Two magma series and associated ore deposit types in the Permian Emeishan large igneous province, SW China; Lithos 103(3) 352-368.

Zhu D, Pan G, Mo X, Liao Z, Jiang X, Wang L and Zhao Z 2007 Petrogenesis of volcanic rocks in the Sangxiu Formation, central segment of Tethyan Himalaya: A probable example of plumelithosphere interaction; J. Asian Earth Sci. 29(2) 320335.

Zindler A and Hart S R 1986 Chemical geodynamics; Ann. Rev. Earth Planet. Sci. 14 493-571. 